$5-1-2012$

\title{
Residual Effects of an Elementary Theatre Program
}

Karen D. Dietry

Cedarville University

Follow this and additional works at: http://digitalcommons.cedarville.edu/education_theses

Part of the Art Education Commons, and the Elementary Education and Teaching Commons

\section{Recommended Citation}

Dietry, Karen D., "Residual Effects of an Elementary Theatre Program" (2012). Master of Education Research Theses. 41.

http://digitalcommons.cedarville.edu/education_theses/41

This Thesis is brought to you for free and open access by 
RESIDUAL EFFECTS OF AN ELEMENTARY THEATRE PROGRAM

A thesis submitted in partial fulfillment

Of the requirements for the degree of

Master of Education

By

KAREN DELAYNE DIETRY

B.A. Elementary Education, Cedarville University, 2001

2012

Cedarville University 
CEDARVILLE UNIVERSITY

SCHOOL OF GRADUATE STUDIES

May 1, 2012

I HEREBY RECOMMEND THAT THE THESIS PREPARED UNDER MY

SUPERVISION BY Karen Delayne Dietry ENTITLED Residual Effects of an

Elementary Theatre Program BE ACCEPTED IN PARTIAL FULFILLMENT OF THE

REQUIREMENTS FOR THE DEGREE OF Master of Education.

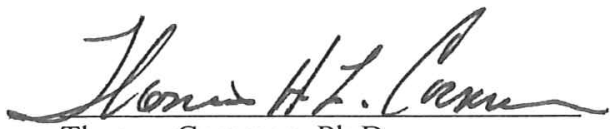

Thomas Conman, Ph.D.

Academic Vice President

Michouew. Fin

Michael W. Firmin, Ph.D.

Psychology Department Professor

Thesis Advisor
Marks McClain

Mark McClain, Ph.D.

Associate Academic Vice President

College of Professions

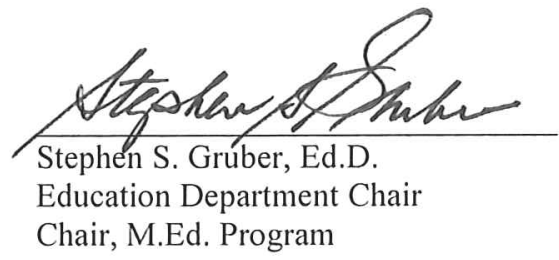

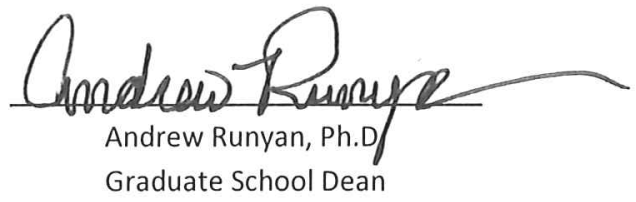




\begin{abstract}
Dietry, Karen D. M.Ed., Education Department, Cedarville University, 2012. Residual Effects of an Elementary Theatre Program.
\end{abstract}

This qualitative study reports student perceptions regarding residual effects of participation in an elementary school theatre program. The study was based on interviews of 22 students who were 11-16 years old and who attended a public school in a rural Midwestern community. Results showed that students perceived the following effects of participation in an elementary play: development of academic and personal life skills that were transferred to other areas of life, increased development of personal traits, such as self-confidence, development of positive social networks, and stimulated desire for continued involvement with performing arts. 


\section{TABLE OF CONTENTS}

Page

I. INTRODUCTION AND PURPOSE $\ldots \ldots \ldots \ldots \ldots \ldots \ldots \ldots \ldots \ldots \ldots$

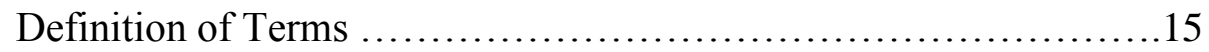

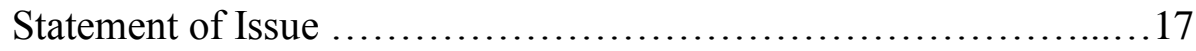

Scope of the Study and Delimitations ............................18

Significance of the Study .................................... 19

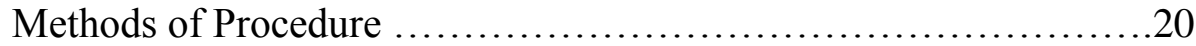

II. PLENARY LITERATURE REVIEW ...........................20

Effects of Creative Drama and Theatre-Based Programs ............23

Academic development ...................................24

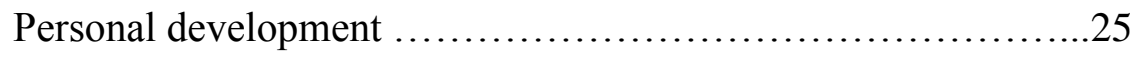

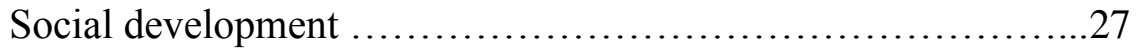

Effects of Participation in High School Extracurricular Activities ...29

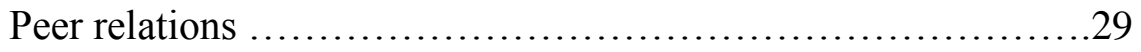

School connectedness .......................................30

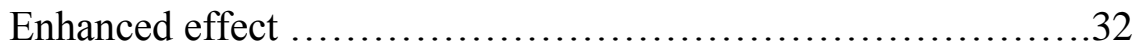

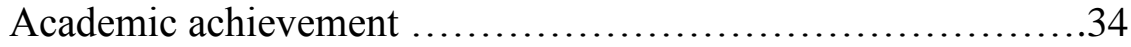

Effects of Participation in Middle School Extracurricular Activities .36

Effects of Elementary School Extracurricular Activities .............37 


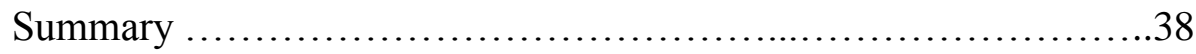

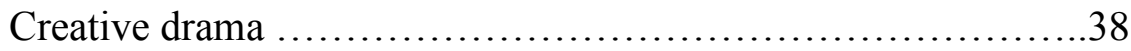

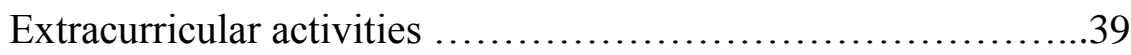

III. METHODOLOGY …....................................... 42

Rationale for the Method ......................................42

Population of the Study ..........................................43

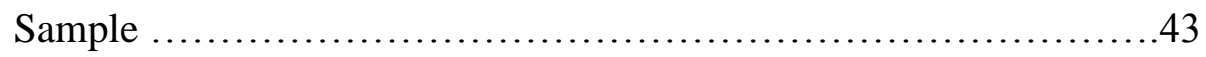

Sample criteria and method of sampling .......................43

Rationale for the sample ...................................43

Procedure ......................................................... 44

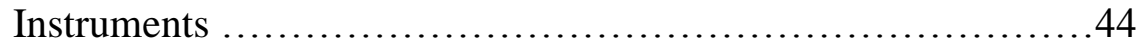

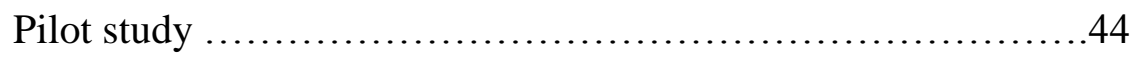

Data collection methods ....................................44

Relevant ethical considerations ...............................45

Methods of data analysis .....................................46

Safeguards to internal and external validity ....................47

IV. QUALITATIVE ANALYSIS .................................49

Academic Effects ..............................................49

Memorization ............................................. 49

Public speaking ...............................................51 
Personal Effects ...............................................53

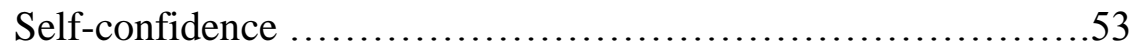

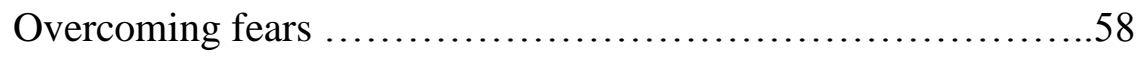

Making mistakes ......................................60

Practicing ............................................62

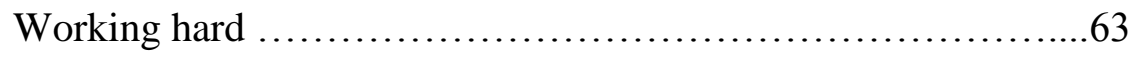

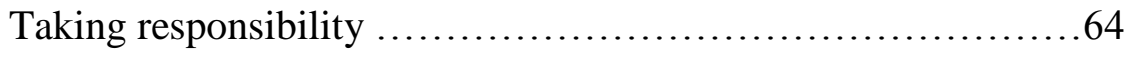

Social Effects ...........................................65

Teamwork ...........................................65

Positive social networks ..................................67

Peer social networks ..................................69

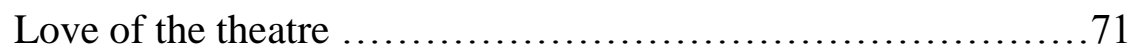

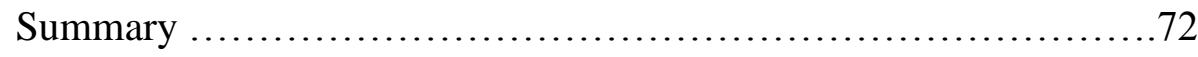

V. DISCUSSION AND IMPLICATIONS ........................73

Interpretation of the Results ...............................73

Improvement of specific academic-related skills ..............74

Set a positive trajectory for future utilization of enhanced verbal

abilities ............................................... 74

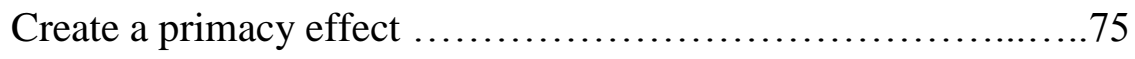

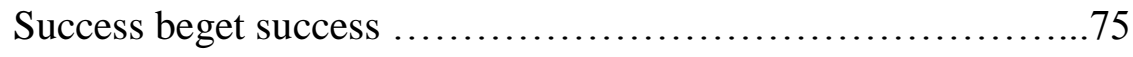

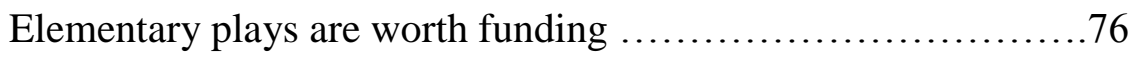


Potential Applications of the Findings

Devote adequate attention to the design of an elementary theatre

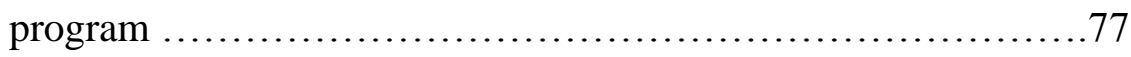

Incorporate opportunities for future interactions $\ldots \ldots \ldots \ldots \ldots \ldots 77$

Provide funding for continued theatre programs ................78

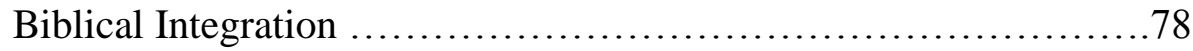

Relation of the Results to Literature .............................80

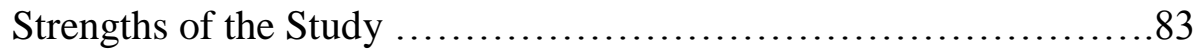

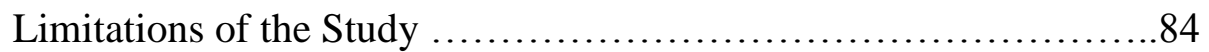

Remaining threats to internal validity $\ldots \ldots \ldots \ldots \ldots \ldots \ldots \ldots . . . . . . . .64$

Remaining threats to external validity $\ldots \ldots \ldots \ldots \ldots \ldots \ldots \ldots \ldots . \ldots \ldots$

Suggestions for Future Research ...............................86

VI. APPENDICES $\ldots \ldots \ldots \ldots \ldots \ldots \ldots \ldots \ldots \ldots \ldots \ldots \ldots \ldots \ldots \ldots \ldots \ldots$

Appendix A: First Wave Interview Questions ....................88

Appendix B: Second Wave Interview Questions .................91

Appendix C: Parent Letter/Permission Slip ......................93

VII. REFERENCES ............................................. 95 


\section{ACKNOWLEDGEMENTS}

Thank you to my husband and children for all of your support and time as I completed this project. I could not have finished without you.

Thank you, also, to my parents and extended family who supported and prodded the completion of the research. Thanks for believing I could finish this.

Thank you to the Jonathan Alder School District faculty, staff and students. It is truly my privilege to be part of the JA family.

Thank you, Dr. Firmin, for all of the time and energy you put into this paper as my

advisor. I appreciate your willingness to make my goal of completion, your goal.

And to my Lord and Savior, Jesus Christ, I give my greatest praise and thanksgiving. Thank you for guiding my steps all the days of my life and throughout the process of this project. May this project and my life give glory to Your Name. 


\section{Chapter One: Introduction}

Extracurricular activities can provide unique learning opportunities for young people. Many researchers believe that participation in extracurricular activities impacts students through three primary means. These include strengthening their connections to school, improving academic achievement, building positive social networks, and developing individual strengths (Cosden, Morrison, Gutierrez, \& Brown, 2004). These conclusions address mainly high school extracurricular opportunities.

First, extracurricular activities engage students, thus connecting them to their school environments. McNeal (1999) noted that a clear link exists between student involvement in after-school activities and a safe and positive school climate. This link appears to be cyclical. When students feel safe at school, then they are often more likely to become involved in activities due to their school environment perception. Frederick and Eccles (2006) linked the duration of student participation in after-school activities with having an overall higher sense of school belonging. The longer students participated in extracurricular activities, the more they felt they belonged to the school community.

Klem and Connell (2004) recognized that a benefit of engagement with school includes a relationship between student connectedness and academic performance. As students become more attached to their school, their academic performance increases. Students earn higher grades as a result of participation in various forms of extracurricular 
activities. Broh (2002) stated that participation in sports increased students' English and math grades, and Shulruf (2010) noted that students who participated in academic clubs also had higher grades. Furthermore, Fredricks and Eccles (2006) reported that the longer students participated in extracurricular activities, the more likely they were to have better grades. Additionally, students tend to be more attentive in class due to participation in extracurricular activities (Barnett, 2007).

Hunt (2005) disagreed that school engagement aids learning. He found that the opposite may be true, that getting good grades increases school engagement. He conducted a study regarding the influence of sophomores' extracurricular activities on their academic performance in their senior year of high school. In his sample, participation in extracurricular activities did not improve grades. Instead, he found that earning better grades as sophomores may have led to participation in more extracurricular activities when they become seniors.

A second potential benefit of extracurricular activities is that they facilitate building positive social networks. Fredericks and Eccles (2005) found that students' involvement in school extracurricular activities influenced their selection of friends, thereby helping to shape students' value systems. For this reason, Gilman, Meyers, and Perez (2004) encouraged school psychologists to promote structured extracurricular activities (SEA), because these activities have the potential to positively affect the social networks of at-risk teens.

One way that SEAs promote a positive social network, specifically relating to athletic teams, involves facilitating a sense of team spirit (Cassel, Chow, Demouli, \& Reiger, 2001). Students are able to recognize that all the members of the team are 
essential to its success. This sense of team unity potentially can become a transferable tendency throughout an individual's life.

Third, extracurricular activities also can improve the development of students' individual strengths, thereby increasing self-esteem. For instance, Broh (2002) studied the benefits of participation in interscholastic sports on high school students. He found that participation in sports improved students' self-esteem. Similarly, Gadbois and Bowker (2007) reported that participation in athletic extracurricular activities enhanced positive self-perceptions for males. Additionally, they determined that participation in non-athletic activities developed self-esteem for females.

While some researchers focus on the advantages of extracurricular activities in the high school arena, research pertaining to the effects of elementary extracurricular activities is more limited. For example, Dumais (2006) conducted a study using data from kindergarten and first graders. She found that participation in extracurricular activities in the early years seemed to affect later gains in reading achievement test scores and teachers' evaluations of math skills. Dumais noted that students who are less privileged economically particularly benefited from involvement in SEAs.

The main pool of research concerning extracurricular activities combines either all of the potential activities or centers on school sports (Broh, 2002). As a result, there is limited research specifically relating to the effects of theatre on young people in high school. Moreover, less research exists concerning the effects of drama as an after-school activity in the elementary arena.

The existing literature regarding the use of creative drama in elementary education suggests two main benefits. First, creative drama can improve elementary 
students' thinking skills. Furman (2000) attempted to empirically show some value of using drama in early childhood education. He reported that dramatic play in an educational setting can promote cognitive development for students. Moreover, Johnson (2002) concluded that, since drama is capable of enhancing children's thinking skills, it should be utilized frequently in elementary school. Cockett (1999) found that teachers deemed the use of thinking skills as a vital component of the creative drama process. They evaluated the use of children's critical thinking skills as part of the assessment process.

A second potential benefit of creative drama in elementary classrooms is the improvement of students' relational skills. For example, Walsh-Bowers and Basso (1999) described two creative drama programs, one rural and the other urban, and discussed the effectiveness of those programs in improving peer relations. Students from both schools felt more confident in their abilities to deal with their peers through cooperation and respect. In addition, Bates (2007) reported that creative drama can teach students important life lessons and skills, such as teamwork and self-confidence. Furthermore, Rosler (2008) described a fifth grade social studies classroom in which process drama was used. Students interacted with the class material via process drama, resulting in collaboration and development of leadership skills. Each of these studies reflected some form of increased relational skills as a result of creative drama in the classroom.

Researchers reported two main benefits of utilizing creative drama in high school: social benefits and increased self-confidence. For instance, Yassa (1999) conducted a qualitative study of high school students' perceptions regarding their creative drama 
participation and the effect this involvement had on their social interactions. Her findings suggest that involvement in drama can enhance social interaction and self-confidence. Congruently, Maples (2007) studied the use of improvisation in a middle school English class and determined that the use of drama helped to develop community and confidence.

Creative drama is used by educators both within the context of the classroom proper, as well as outside of the direct school environment. The latter category can be divided into two main categories: international social programs and national theatrebased programs. Some researchers have addressed specific international social programs that involved drama in some capacity. For example, Munier and Etherton (2006) observed that the girls who had participated in a Theatre for Development training workshop in northern Bangladesh were more confident five years after the program ended. Improved self-confidence had been one of the goals of the theatre program. Dalrymple (2006) conducted a study of the impact an AIDS prevention program had on participants in South Africa. Participants reported several benefits from involvement in the program. First, students felt an increased sense of self-efficacy enabling them to cope with their disease. Second, students reported increased critical thinking skills as they pertained to analyzing the motives behind others' actions.

Researchers also have conducted studies of non-school-based theatre programs within the United States. For example, Farris and Parke (1993) conducted an ethnographic study relating to summer drama program for suburban gifted and talented students. As a result of the program, students developed theatre skills and used selfevaluation techniques. The participants reported the development and improvement of several skills, including reading with expression, collaboration, cooperation, 
improvisation, thinking skills, and public speaking skills. Additional national research occurred regarding at-risk inner city youth. First, Shirer (2005) discussed the My True Voice Project which focused on teaching at-risk students both thinking and traditional skills, as well as building community. Similarly, Kisiel et al. (2006) evaluated a theatrebased youth violence prevention program (YVP) involving inner city elementary students. The researchers reported that students involved in the program demonstrated fewer aggressive behaviors, better pro-social behaviors, and increased attention in and engagement with school when compared with students who had not attended the YVP.

Research in the fields of general school-related extracurricular activities and creative drama report some similar benefits and outcomes. Unfortunately, research regarding the effects of theatre-specific extracurricular activities in school is limited. Nonetheless, the reported effects of this limited research seem to align with its counterparts. For instance, in a grounded theory analysis of high school theatre, Larson and Brown (2007) detailed the process that a group of high school theatre students underwent as they experienced positive emotional development. The students related their experiences with being involved in a show, specifically addressing disappointment at casting time, excitement as mastery over characters occurred, as well as stress and anger as they dealt with a difficult dialect coach. Additionally, Hughes and Wilson (2004) focused their research on the impact that youth theatre had on a sample of young people. Their findings showed congruence with many of the reported results of research relating to high school extracurricular activities. The students' comments unmistakably linked involvement with a youth theatre program to increased competence interacting 
with peers, adults, and teachers. These British children also felt that involvement improved their ability to "be themselves" and "express themselves" more efficiently.

Additional research is needed regarding the effects of theatre-specific extracurricular activities of elementary students (Hughes \& Wilson, 2004; Larson \& Brown, 2007). Little is known about the educational relevance of such programs. The initial exploratory research in the field of elementary extracurricular activities has leant itself to qualitative methodology. For example, Fleming, Merrell and Tymms (2004) purported that artistic areas such as the theatre are, by their nature, easily aligned with qualitative approaches to systematic inquiry. They are not suggesting quantitative research should be avoided among the creative arts. Rather, the ambiguities and complexities of the arts are more easily appraised through qualitative means, as opposed to numerically, via quantitative methods.

\section{Definition of Terms}

Academic Self- Concept - The way students view their drive to achieve mathematical ability, writing ability, as well as creativity and confidence in their intellectual ability (House, 2000).

Creative Drama - The preferred term for the use of theatre arts for educational purposes. The end goal is to encourage development of student participants' growth, rather than to give a final performance for an audience (Freeman, Sullivan, \& Fulton, 2003).

Drama Anxiety - Feelings of anxiousness related to participation in workshop situations involving drama (Wright, 1999). 
Educational Resilience - Trait exhibited by at-risk adolescents in which they unexpectedly continue on to college after high school in spite of social and personal history (Peck, Roeser, Zarrett, \& Eccles, 2008).

Engagement - The behaviors, emotions and thought processes a student undergoes during a school day. It specifically relates to the link between how students feel about school relative to their achievement in school (Klem \& Connell, 2004).

Impact - The effect of an activity or experience has had on its target audience (Dalrymple, 2006)

Latch-key - A before and after school program in which students are provided childcare services (Cosden et al., 2004).

Lifespace Configurations - Adolescents' overall view of their personal and social risks and assets (Peck et al., 2008).

School Connectedness - The cognitive dimension of school engagement by which students view their school in a positive manner (Dotterer, McHale, \& Crouter, 2007).

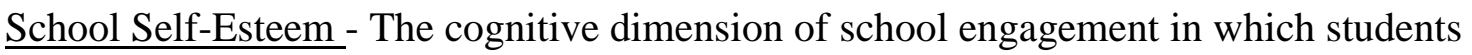
view their school in a positive manner (Dotterer et al., 2007).

$\underline{\text { Social Capital - Extended sets of social networks and students' access to adult-supervised }}$ activities (McNeal, Jr., 1999).

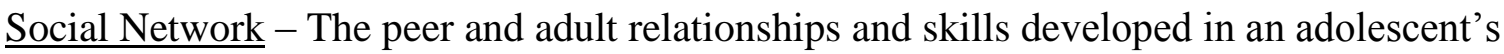
life (McNeal, Jr., 1999).

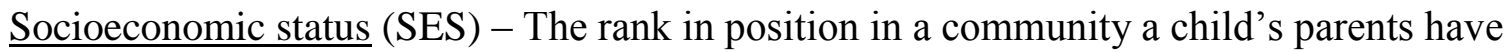
based on financial stability (Dumais, 2006). 


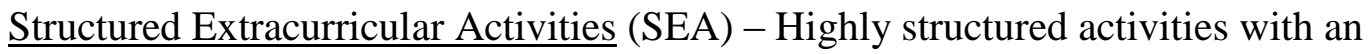
emphasis on building skills, which are facilitated by a non-parent adult (Gilman et al., 2004)

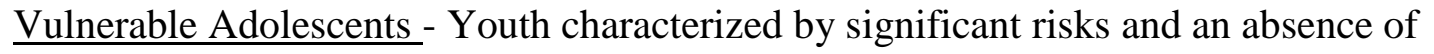
assets (Peck et al., 2008).

Youth Theatre - A term that encompasses a wide variety of groups with a purpose in engaging young people in theatre activities, typically outside of the formal school setting (Hughes \& Wilson, 2004).

Youth Violence Program (YVP)-A program developed for inner-city youth which focuses on aggressive behaviors, prosocial behaviors and scholastic attention and engagement (Kisiel et al., 2006).

Statement of Issue

Extracurricular activities are prevalent in high schools across the country. High school students can choose to be involved in a number of activities, such as athletics, cheerleading, drama, yearbook, and the like (Hansen, Larson, \& Dworkin, 2003). However, the opportunity for elementary school youths to participate in a cost-free extracurricular activity is relatively rare, and research in the area of the potential effects that children's theatre has on the lives of elementary students is rare. While Hughes and Wilson (2004) conducted research concerning a youth theatre in England, little has been said about a school-funded theatre production in the United States.

In 2003, Plain City Elementary of the Jonathan Alder Local School District presented its first children's theatre play. Each consecutive year, a new play was presented. Over the course of following years, a formal children's theatre program was 
added to the school district's middle school and junior high school. While positive feedback at the time of each elementary play was related by cast members, little is known about the residual effects on the students who were involved. Students who participated in the plays were required to audition for parts, memorize their lines, participate in daily rehearsals, and perform the play twice. Each year, since 2003, 60 or more students competed for approximately 25 speaking parts.

As stated previously, the research concerning high school extracurricular activities shows that older students may be impacted by participation in extracurricular activities in three ways: connections to the school, positive social group interactions, and personal development (Cosden et al., 2004). It is unclear whether the same positive outcomes would impact the elementary students who participated in this particular program. Furthermore, limited research exists demonstrating whether any of the skills that students learned and utilized on-stage has continued over time in their daily lives.

\section{Scope of the Study and Delimitations}

In this action research study, I collected data on students' perceptions regarding the residual effects of participation in a children's theatre program. I interviewed 22 students, ages 11 through 16 years old, who had a part with 15 or more lines in the play. I interviewed all of the students who met these criteria and whose parents completed and returned the permission form. These students were part of a small, rural public school. While I did not completely replicate the study, I modeled many of my questions after Hughes and Wilson's (2004) study conducted in England concerning youth theatre.

Because I was the children's theatre program director, there was a need to guard against researcher bias. As a result, two third-party-assistants interviewed the students. 
Also, neither parents nor teachers were interviewed in the process of this project. While the teacher and parent response would be informative, that particular data was outside the purview of my research question. Since this was an action research study, I did not focus on plays performed outside of Plain City Elementary School.

\section{Significance of the Study}

Students' participation in extracurricular activities has several potential personal and educational benefits. The school system, with the monetary assistance of the Parent Teacher Organization (PTO), devotes a significant amount of time, money, and human energy to annual productions. Consequently, it is advantageous to know whether these kinds of activities are productive and beneficial for future Plain City Elementary students. In order for the school district to realize the validity of such a program, research aimed at outcomes assessment is warranted.

Another reason to conduct this particular study is that a significant paucity of research exists in the area of children's theatre. There are many school districts that incorporate after-school activities without apt research supporting its worth. Providing empirical evidence to help show the lasting outcomes of theatre exposure better justifies the expenditure of capital and resources toward these programs.

Also important, the present study is of particular potential benefit for the students who participated in the project as they reflect on perceived outcomes. This type of selfevaluation through questioning was studied by Kelin (2007) who stated that the use of teacher-led questioning enabled students to process their experiences as they pertain to the theatre. Similarly, I believe that this action research study can provide the 
opportunity for students involved in the children's theatre program to reflect on and evaluate their own learning experiences.

\section{Methods of Procedure}

\section{Research questions:}

1. Were any skills used or introduced in the theatre program transferable to other areas of the students' lives, whether academic or personal in nature?

2. What were the personal benefits of participation in the theatre program?

3. Did any peer/social networks form as a result of the theatre program?

4. Is there any evidence of students' future participation in performing arts that were impacted by past participation?

This action research focused on students' perceptions of the residual effects regarding their participation in a children's theatre program. As a phenomenological, qualitative research study, I interviewed 22 students who held leading roles in any of the children's plays. I operationally defined leading role as having 15 or more lines in the play. Since this was an inductive approach to the research topic, I collected the data, searched for patterns within the data, and generated hypotheses regarding the data the students provided (Sin, 2010). In the end, I sought to assess what influence the children's theatre program had on the students involved.

Utilizing third-party interviewers, I conducted the interviews in two waves (Firmin, 2006). The first wave spanned a one-week period in May, and the second wave of interviews lasted one day in August. I began by interviewing all students who met the criteria. This took approximately four days. After I collected this data set, I analyzed it in order to determine which students should be interviewed further in a second wave of 
interviews. I interviewed those students approximately three months after the first wave of interviews. At the completion of the second wave of interviews, a focus group (Del Rio-Roberts, 2011; Wilkinson, 1997) met in order to discuss additional topics of interest relating to the previous interviews. Upon completion and evaluation of the second set of interviews and focus group, it was clear that the data had reached saturation.

I conducted this study using an inductive approach for phenomenological qualitative protocol (Wertz et al., 2011). Students were interviewed in two waves using standard interview questions involving three major constructs: academic, personal and social network effects of participation in an elementary children's play (Johnson, 2008). The primary means of data collection was interviews, which was supported by a focus group. The data was then coded following Maxwell's (2005) open coding structure. Using constant comparison (Johnson \& Christensen, 2004), I assessed the codes for repeated words, phrases, and overall themes (Bereska, 2003). Themes lacking support were eventually discarded (Fereday \& Muir-Cochrane, 2006), while others were combined and condensed into similar constructs (Rubin \& Rubin, 1995). I used thirdparty-interviewers, low-inference descriptors, and triangulation in order to safeguard the internal validity of my findings (Kvale, 2007; Patton, 2001).

Member checking (Mero-Jaffe, 2011) helped to ensure that the findings I reported from the study were apt reflections of the participants' true sentiments. Additionally, reviewing of the project by a qualitative research expert who was apart from the data collection and coding process helped to safeguard the study's internal validity (Cope, 2004). This review was strengthened by generating a data trail (Rodgers, 2008). This involved the study's main themes and the supporting transcript that girded the reported 
findings. The themes reported reflect the common sentiments shared by most of the participants. 
Chapter Two: Plenary Literature Review

Two main schools of research are most germane regarding elementary students involved in theatre arts after-school programs. First, the literature addresses the benefits and validity of creative drama, within and apart from the context of school. Second, researchers have conducted studies devoted to students' general involvement in extracurricular activities and the potential benefits and repercussions therein.

\section{Effects of Creative Drama and Theatre Based Programs}

The use of creative drama and theatre-based programs as a means of impacting people is versatile and global. It exists in all levels of education, from primary school to post-secondary classrooms (Cocket, 1999; Freeman et al., 2003; Joronen, Konu, Rankin, \& Astedt-Kurki, 2012; Maples, 2007; Rosler, 2008; Walsh-Bowers \& Basso, 1999; Wright, 1999; Yassa, 1999). Within the context of school, they are utilized with innercity students (Kisiel et al., 2006; Shirer, 2005), gifted and talented students (Farris \& Parke, 1993), and students attending both public and charter schools (Boldt, \& Brooks, 2006; Cockett, 1999; Freeman et al., 2003). Outcome research even exists regarding the use of theatre as a prison performing arts program in Pacific, Missouri (Dufresne, 2006). In addition to being versatile, the use of creative drama and theatre-based programs is global, used with Canadians (Yassa, 1999), English (Fleming et al., 2004; Johnson, 2002), Africans (Casale \& Hanass-Hancock, 2011; Dalrymple, 2006), and youth in Bangladesh (Munier \& Etherton, 2006), to name a few. 
Academic Development. Involvement in classroom creative drama and theatrebased programs can affect three different components of academic development. First, academic achievement in specific content areas can be improved. For example, Fleming et al. (2004) reported research results relating to The National Theatre's Transformation drama project. Differences in mathematics academic achievement were shown to be statistically significant when comparing the control group to the drama group. Language arts achievement also improved. Shirer (2005) reported that two benefits of the My True Voice Project, a mentorship program developed to teach inner city students communication skills using various principles of theatre education, included improved spelling skills and an expanded vocabulary. She also discussed the potential for improvement in reading comprehension and writing skills. Congruent with these language arts benefits, Maples (2007) discussed using improvisation in her middle school English classes in order to aid students to interact with the class texts in meaningful ways. Specifically, she discussed that the classroom drama reflected apt details from the social studies textbook and trade books that students had read.

A second academic impact that both creative drama and theatre-based programs can have on adolescents involves improved metacognitive skills. Researchers have noted this benefit and commended the use of creative drama within the classroom. For example, Furman (2000) discussed the use of dramatic play in early childhood education. He noted that, within this educational setting, dramatic play enriches cognitive development. Furthermore, Johnson (2002) conducted a study involving creative drama and its metacognitive effects on elementary students. She concluded that drama can 
improve both children's thinking skills and metacognition, thereby enhancing the learning process.

Third, teachers have recognized the influence of creative drama on students' critical thinking skills. Cockett (1999) documented this by using the evaluation ratings of primary teachers in England. He studied the criteria teachers used to assess children's learning in classrooms that incorporated creative drama. One of the main evaluation categories included students' thinking skills. Specifically, teachers expected students to develop and utilize critical reflection throughout the various dramatic activities in class.

Fourth, researchers of theatre-based programs also have reported the academic benefits in adolescents' improved thinking skills. One example comes from Shirer (2005) who reported that a noted benefit of participation in the My True Voice Project was that students developed enhanced critical thinking skills. Students in the program were encouraged to become more creative thinkers, as well. Another example comes from Dalrymple (2006) who studied the impact of a drama for AIDS education program in South Africa. She found that the participants in the program reported the ability to think more critically about the motives of others.

A final academic impact that both creative drama and theatre-based programs can have on adolescents is increased student classroom participation. Regarding creative drama's impact on increased classroom involvement, Maples (2007) reported two outcomes of improvisation's use in the classroom. First, students interacted differently due to the classroom format. Second, students of all ability levels participated more in class. Rosler (2008) also discussed the impact of creative drama on students in class. She interviewed students of a fifth grade social studies class using process drama in 
which the students discussed both their lack of engagement when process drama was not used in class, as well as their increased engagement in class when they were able to use the process drama.

Drama used in theatre-based programs also improved students' classroom participation in school. For example, Kisiel et al. (2006) researched a youth violence prevention (YVP) program for inner city elementary students. They reported that the YVP was shown to have increased engagement and attention in class. Teachers related that students who had been involved in the YVP displayed less hyperactivity and more engagement in classroom lessons. Comparatively, students who had not participated in the YVP demonstrated an increase in hyperactivity and less engagement in classroom lessons.

Personal Development. In addition to academic development, student's behavior and personal development also may benefit from participation in a theatre arts based program or class. First, participation in theatre arts based activities can increase students' self-confidence. Bates (2007) promoted the process of adapting literature for children's theatre so that the act of acting would develop self-confidence in young people. Also, Munier and Etherton (2006) reported confidence as an outcome of adolescents' participation in a Theatre for Development training workshop in rural Bangladesh. Five years after completing the workshop, the researchers reported observations that female participants in the program showed measurable increases in confidence levels.

A second potential benefit of participation in theatre-based programs and classes is enhanced self-concept. Fleming et al. (2004) studied the impact of The National Theatre's Transformation drama project in England on elementary students. The 
researchers reported that students involved in the project related more positive selfconcepts than students who had not participated in the program. Participants were proud of what they had accomplished, and they also conveyed liking who they were as individuals.

However, not all research is congruent as it pertains to the improvement of students' self-concept. In particular, Freeman et al. (2003) conducted a study regarding the effects of creative drama on the self-concept of elementary students. Their findings did not support the use of creative drama to improve self-concept. They suggested that changes in the duration of the creative drama activities could influence self-concept more positively.

Research has been conducted regarding other potential personal benefits of participation in creative drama. First, Hughes and Wilson (2004) noted several enhanced personal skills that tend to be developed, such as risk taking and exploring and expressing one's thoughts and feelings. Second, Farris and Parke (1993) reported that gifted students benefited from self-evaluation as it pertained to participation in a summer theatre program. Third, Dalrymple (2006) stated that participants in the Drama for AIDS Education program revealed increased self-efficacy. Last, Kisiel et al. (2006) noted that the classroom teachers of students involved in a theatre-based YVP saw an improvement in participants' self-control.

Social Development. In addition to academic and personal development, the enhancement of social skills is another potential benefit from participation in a theatre arts based program or class. Some researchers have generalized how creative drama affects students. For example, Kisiel et al. (2006) reported that inner city fourth graders 
involved in a YVP showed an improvement in social skills in comparison with students not in the program. Other researchers specified areas of improvement within the realm of social skill development. For instance, Rosler (2008) discussed the development of leadership skills for particular students as they participated in a classroom process drama. Also, Yassa (1999) identified various social skills that can be advanced as a result of active participation in drama, including empathy, tolerance, and adaptability.

The most commonly noted social skill-set improved through classroom drama in the research literature is cooperation, collaboration, or teamwork. First, Yassa (1999) believed that, within a dramatic framework, students learn problem-solving skills and are able to reconcile their differences. Also, gifted students involved in a qualitative study of a summer drama program were able to participate in a milieu where everyone was accepted, and students showed improvements in their cooperation with one another at the conclusion of the program (Farris \& Parke, 1993). In addition, Walsh-Bowers and Basso (1999) evaluated two creative drama programs working with seventh graders. One objective of the program was to improve students' peer relations. They found that this goal was partially met. Students of the program listed social skills such as cooperation, solving disagreements, and empathy feelings for others within the program as noted areas of personal improvement. Bates (2007) further corroborated the ideas of teaching collaborative and teamwork skills through integrating classroom drama, but also included a sense of trust as an impact of drama based programs. The mentor relationship between youth and program leaders is also mentioned in the My True Voice Project review (Shirer, 2005). 
The majority of the research literature delineates a positive link between creative drama and theatre-based programs to improved social skills. As an exception, Freeman et al. (2003) reported that data from their study of third and fourth graders did not support improvement of social skills to be linked to creative drama. However, relatively half of the 237 students within the sample were not pretested before the program began and, therefore, a follow-up ANCOVA was unavailable.

\section{Effects of Participation in High School Extracurricular Activities}

Peer Relations. Although most research about extracurricular activities focuses on high school students, some data also exists that focuses on middle school and elementary students. Research regarding the effects of high school extracurricular activities can be divided into four main categories: peer relations, school connectedness, personal development, and academic development. Pitts (2007) conducted a case study of a British secondary school's production of Anything Goes. As part of the study, students reported that the show provided social opportunities and generated friendships. Extracurricular activities also can provide a feeling of belonging to a group and "a sense of family" (Cassel et al., 2001; Fredricks \& Eccles, 2005).

Participation in school based extracurricular activities can affect the students' decisions to befriend peers with "risky behaviors." For example, students involved in school clubs and activities were shown to be less likely to have peers who make risky decisions such as drinking, smoking, and using drugs. This is specifically true for students involved in the performing arts and academic clubs concerning alcohol (Fredricks \& Eccles, 2005; Fredricks \& Eccles, 2006). There is, however, one exception: 
athletics often is linked to increased underage drinking (Eccles, Barber, Stone, \& Hunt, 2003).

Fredricks and Eccles (2005) also hypothesized and provided quantitative evidence that participation in extracurricular activities predicted some defining qualities of students' friendship groups. Additionally, they predicted that these friendship networks can be catalysts for school engagement, as well as personal and academic development. Moreover, Broh (2002) stated that students involved in high school athletics are likely to have an increased number of academically minded peers. As a result of observing these potential outcomes, Gilman et al. (2004) encouraged school counselors to guide at-risk teens into structured, extracurricular activities.

School Connectedness. Involvement in prosocial peer groups, due to participation in extracurricular activities, significantly predicts a sense of school belonging (Fredricks \& Eccles, 2005). Corroborating this conclusion, McNeely, Nonnemaker, and Blum (2002) reported that, in conjunction with earning higher grades and regular school attendance, students in their sample who participated in extracurricular activities tended to feel more "attached" to their school. This feeling of connectedness to school is further illustrated in Barnett's (2007) study regarding the effects of being included or denied participation on a high school cheerleading squad as a result of an audition selection process. Girls in this study who made the team reported that they wanted to go to school. Conversely, the unsuccessful girls' feelings of school connectedness dramatically decreased and stayed that way for several weeks, sometimes into months. More recently, Knifsend and Graham (2012) found that upperclassmen who participated in at least two 
extracurricular domains reported a greater sense of belonging to school than those who were not as involved in after-school clubs and athletics.

Additionally, Eccles et al. (2003) examined the effects of dropping out of sports in high school. Involvement in extracurricular activities provides a natural link to school connectedness and dropping out of sports, particularly for an academically challenged student, may weaken the student's sense of school attachment once participation is ceased. Regarding athletics, Fredericks and Eccles (2006) determined that one benefit of continuous participation in high school sports for upper-classmen was increased feelings of belonging to the school. As part of the same study, the authors also determined that consistent participation in adult-supervised, meaningful extracurricular activities can be associated with opportunities for belonging.

In a comparison study of four ethnic groups, Faircloth and Hamm (2005) combined several school experiences in order to determine each group's sense of belonging in school. They determined that relationships with teachers, positive peer interaction, participation in school activities, and perceived discrimination were relevant for Euro-Americans and Latino students. African-American and Asian-American students reported a greater sense of belonging as a result of only three elements: relationship with teachers, school activity involvement, and perceived ethnic-based discrimination.

A smaller subset of school attachment's potential effects involves connectedness to non-familial adults within the school culture. Pitts' (2007) case study reported that participants felt they developed enhanced relationships with the teachers when involved in a school musical. Furthermore, she related portions of an audio diary in which a 
student evaluated and empathized with the teacher's leadership tasks. Audio diaries and interviews from the case study affirmed the student's enhanced sensitivity to the teacher's responsibilities. This sense of student to teacher connectedness may positively affect the adolescents' personal development, specifically relating to students engaged in a range of extracurricular activities (Fredricks \& Eccles, 2006). Eccles et al. (2003) related that students often possess greater teacher access for advice on academic and occupational plans, as well as personal problems, when involved in extracurricular activities, especially sports.

Enhanced Affect. This potential link between participation in extracurricular activities and adolescents' personal development threads its way throughout research literature. While Hansen et al. (2003) reported that students experience personal life skill benefits, such as goal setting, problem solving, and time management, the majority of the research relates to the psychological and emotional effects of participation in high school extracurricular activities. For example, Fredricks and Eccles (2005) correlated activity participation to lower depression in adolescents. They suggested that this may partly be due to the prosocial peer relationships discussed previously that provide support and lessen the sense of social isolation. Further findings showed that, rather than being stressed-out, the oldest cohort of students actually thrived with multiple activity participation. These students were predicted to have higher resilience skills and lower distress (Fredricks \& Eccles, 2006).

Students participating in extracurricular activities also may have both positive and negative emotional effects due to participation in the various programs. Researchers revealed one example of extracurricular activities' positive emotional effects was an 
increased sense of "happiness." Gabrielle (2008) purported that "engagement" is one component to a student's happiness. She stated that students are more likely to relate engagement to activities outside the school day. As such, involvement in extracurricular activities partially predicts the level of happiness a student feels. In a separate study, Barnett (2007) illustrated the emotional responses of female students who were trying out for a school's cheerleading squad. The girls who had been chosen for the team experienced immediate feelings of happiness and felt good about themselves for having made the team. A second example of positive emotional effects of extracurricular activities involved at-risk adolescents. Gilman et al. (2004) reported that enlisting at-risk students' involvement in extracurricular activities may cause them to feel more satisfied with their lives. However, Darling (2005) stated that there was only minimal evidence showing involvement in extracurricular activities to act as an adequate buffer against a large cross-section of negative life experiences.

While participation in extracurricular activities can evoke positive emotions, it can also engender or influence students' negative emotions. These feelings can be affected by athletic extracurricular activities. For example, the girls involved in Barnett's (2007) study who did not make the cheerleading squad reported feeling immediate negative emotions upon hearing they had not been selected for the team. Negative emotions also can be affected by participation in high school theatre. Larson and Brown (2007) recounted that some students' initial responses to casting decisions were negative because they were unhappy with their own roles or the roles of others. These negative emotions lasted approximately 1-2 weeks before students adjusted to their respective roles. These theatre students learned coping skills by managing their own negative 
emotions as they continued involvement in the theater program. These researchers also introduced another potentially negative emotional outcome: increased anxiety, specifically stage fright. However, students in this particular theatre program were able to adequately adjust partly due to peer support.

Hanson et al. (2003) stated that students attributed higher rates of self-knowledge to their participation in performance or fine arts activities, in comparison to other students in the study. Additionally, House (2000) reported that extracurricular involvement can partially improve a student's academic self-concept. A student's self-esteem also can be affected via involvement in extracurricular activities, depending on the extracurricular activity being discussed. Beales and Zemel (1990) claimed that participation in high school drama affected increased social maturity, rather than increased self-esteem. However, Broh (2002) conducted a study on the benefits of athletic extracurricular activities and found that participation in high school sports significantly improved selfesteem in his participants. Moreover, Gadbois and Bowker (2007) reported that both male and female students associated self-esteem with participation in extracurricular activities. Whereas the males' self-esteem had a particular link to athletic participation, the females' self-esteem was more closely linked to the amount of time spent participating in non-athletic activities.

Academic Achievement. Academic achievement is a final category regarding potential effects of involvement in extracurricular activities (Fredricks, 2012). Gilman et al. (2004) encouraged participation in extracurricular activities for at-risk students due to the potential for improved school performance. This improvement was marked by students' improved grades. Participants in Darling's (2005) study also reported enhanced 
grades due to participation in extracurricular activities. Additionally, Fredricks and Eccles (2006) determined that being involved in many activities can relate to achieving higher grades in high school. Also, Knifsend and Graham (2012) found that eleventh graders who participated in at least two extracurricular domains reported higher grade point averages than juniors in high school who were not as involved in after-school activities.

Although grade improvement may be affected by participation in both athletic and non-athletic extracurricular activities, Broh (2002) reported that participation in sports had a relatively small benefit for students' grades in both English and math and for higher test scores on math tests. However, he cautioned that the participation in athletics had less significance on the math test scores, depending on the testing model utilized. In addition, Barnett (2007) recounted that, of the girls trying out for the cheerleading squad, both the "winners" and the "losers" had a week's time where grades decreased and, after that time, the grades of girls in both groups increased and then stabilized.

Students' grades also can improve through participation in non-athletic extracurricular activities. Chambers and Schreiber (2004) noted that participation in school clubs, combined with completing additional homework, resulted in students' attaining higher levels of academic achievement. Additional research in non-athletic extracurricular activities reported similar findings. For example, Shulruf (2010) specified that students who participated in academic clubs achieved higher grades. Also, Lipscomb (2007) stated that participation in after-school clubs resulted was related to a slight increase in math test scores. 
Participation in extracurricular activities also has been shown to increase the likelihood of graduating from high school and attending college (Blomfield \& Barber, 2010; Darling, 2005; Gilman et al., 2004; Guest \& Schneider, 2003). For example, Peck et al. (2008) conducted a study concerning the effects of extracurricular activities as they pertain to college resilience of vulnerable adolescents. In this study, they discovered that at-risk students with negative life experiences who were involved in more than one activity, whether school club, organized sports, volunteer programs, etc., were more likely to apply for and attend college than were at-risk students who were not involved in these activities.

\section{Effects of Middle School Extracurricular Activities}

Research in the field of middle school extracurricular activities is limited, and the results cover a multitude of domains. In a study of both middle school and high school gifted and talented students, Olszewski-Kubilius and Lee (2004) determined that inschool and outside-of-school participation in extracurricular activities was beneficial to determine gifted students' areas of talent and develop those skills with other gifted peers. In a separate study, Dotterer et al. (2007) analyzed the effects of extracurricular activities, specifically school engagement, on African-American middle school students. They found a correlation between time spent in extracurricular activities to school self-esteem and school bonding. They also found that involvement in extracurricular activities did not directly interfere with time spent on homework, potentially affecting grades. Additionally, Akos (2006) studied the effects of participation in extracurricular activities as they pertained to the transition to middle school. He found that participation in middle school extracurricular activities had a degree of impact on GPA, "school connectedness," 
and an overall positive view of the school transition experience from elementary school to middle school. Molineuvo, Bonillo, and Pardo (2010) affirmed these findings regarding Hispanic boys in school. He found that weekly participation in extracurricular activities was associated with higher levels of adjustment to middle school.

\section{Effects of Elementary School Extracurricular Activities}

Findings from research regarding the effects of elementary extracurricular activities are also limited and shows varied results. Some research reported findings related to students' social capital. In analyzing the effects of after-school homework programs, such as "latch-key," on primarily elementary students, Cosden et al. (2004) reported that attendance in these programs can interfere with students' ability to participate in non-academic extracurricular activities. This, in turn, potentially could discourage school bonding, a feeling of connection students' have to their school community. Also mentioned were some potential benefits of extracurricular activities, such as increased school connectedness, improved self-esteem, and positive social networks. Lagace-Seguin and Case (2010) noted a positive relationship between parental support and childhood well-being when children engage in high levels of extracurricular activities. Howie, Lukacs, and Pastor (2010) studied extracurricular involvement of 6-11 year olds. They showed that students who participated in sports and clubs in elementary showed greater social competence than did children who did not participate in any extracurricular activities. These non-participants were less likely to show respect to teachers and neighbors, and they were less likely to get along with other children.

Similarly, Dumais (2006) reported a relationship between elementary extracurricular activities and improved test scores. She found that the quantity of 
extracurricular activities in which an elementary student participated may increase reading test scores. She also noted a relationship between extracurricular activities and teacher perceptions of students' improved math skills. These results were most robust in increasing measure for students from lower socio-economic backgrounds.

Finally, Barnett and Weber (2008) analyzed parental perceptions of extracurricular activities' benefits for their elementary aged children. Mothers attributed more benefits to team sports than to individual sports and performing arts activities. They also believed participation in community recreation activities to have the least amount of benefit. Whereas enhanced social skills was only a perceived benefit of the team and individual sports activities, opportunities to exercise and enhance creativity was attributed to participation in performing arts activities. Skill development also was perceived as a benefit to participation in individual sports activities and performing arts activities. It is important to note here that these were not necessarily realized benefits, but only parental perceptions of the benefits.

\section{Summary}

Creative Drama. Creative drama has been used extensively in classrooms and programs world-wide (Cocket, 1999; Freeman et al., 2003; Jindal-Snape, Vettraino, Lowson, \& McDuff, 2011; Maples, 2007; Rosler, 2008; Walsh-Bowers \& Basso, 1999; Wright, 1999; Yassa, 1999). Three particular academic benefits to the use of creative drama have been denoted in the research literature. First, creative drama is utilized to achieve academic outcomes such as increased math, language arts, reading comprehension and writing skills (Fleming et al., 2004; Shirer, 2005). Second, thinking 
skills are enhanced, which are pivotal to the learning process (Johnson, 2002). A third benefit is increased class participation (Maples, 2007).

However, more than academic outcomes occur as a result of the use of creative drama; behavioral and personal outcomes, both positive and negative, also are affected. Students have reported negative effects of stage fright and anxiety (Wright, 1999). However, studies also have shown positive effects of self-confidence and [potentially] self-esteem (Bates, 2007; Freeman et al., 2003; Fleming et al., 2004). Additionally, the use of creative drama can positively enhance students' social skills (Kisiel et al., 2006). These social skills may have positive outcomes on peer relationships, as well as mentor/student relationships (Walsh-Bowers \& Basso, 1999; Shirer, 2005).

Extracurricular Activities. Extracurricular activities can have positive and negative effects when adolescents move into a high school milieu. Relationally, students can experience an increased sense of belonging to a group (Cassel et al., 2001; Fredricks \& Eccles, 2005). Furthermore, extracurricular activities can assist in creating non-risky relationships with academically-minded peers, as opposed to potentially risky peers with negative behaviors such as alcohol consumption and drug use (Fredricks \& Eccles, 2005; Fredricks \& Eccles, 2006; Eccles et al., 2003). Students also may feel a greater sense of school attachment as a result of participation in extracurricular activities (McNeely et al., 2002).

Positive and negative personal and behavioral outcomes also exist when students participate in extracurricular activities. Participation in extracurricular activities can increase life skills, such as problem solving and goal setting (Hansen et al., 2003). It can also have psychological and emotional outcomes, such as a lowered sense of distress and 
depression (Fredricks \& Eccles, 2005). Participation in extracurricular activities also helps students deal with both positive and negative emotions (Larson \& Brown, 2007). Depending on the extracurricular activity, participation can enhance self-esteem (Gadbois \& Bowker, 2007). However, in relationship to drama, Beales and Zemel (1990) found that it was not self-esteem that was enhanced but, rather, social maturity.

While the majority of the research has been dedicated to the secondary education realm, participation in extracurricular activities also has outcomes for both middle school and elementary adolescents. Gifted and talented middle school students abilities are enhanced by participation in extracurricular activities, specifically drama (OlszewskiKubilius \& Lee, 2004). Furthermore, African-American middle school students' participation in extracurricular activities demonstrated positive self-esteem and increased school attachment (Dotterer et al., 2007). Additionally, both GPA and school connectedness were enhanced due to participation in extracurricular activities, thus enabling an easier transition for middle school students. For elementary students, participation in extracurricular activities resulted in higher reading scores (Dumais, 2006). Furthermore, Barnett and Webber (2008) reported some perceived benefits that parents of elementary students reported regarding their children's participation in extracurricular activities. Concerning theatre, parents perceived increased creativity and skill development, but not enhanced social skills.

Research pertaining to creative drama, theatre based programs, and extracurricular activities purported several recurring potential effects for adolescents: academic, social, and behavioral effects. While creative drama incorporates similar features of a children's theatre program as a structured extracurricular activity (SEA), it is 
not considered to be a formal SEA (Gilman et al., 2004). The results may help form hypotheses pertaining to elementary extracurricular activities, but they cannot formally depict the residual effects of an elementary children's theatre program.

Similarly, the majority of research pertaining to the effects of extracurricular activities remains in the secondary school arena. Furthermore, the secondary school research commonly combines all school clubs and activities together into one or more categories, or focuses solely on athletics as an SEA (e.g., Barnett, 2007; Chambers \& Schreiber, 2004; Darling, 2005; Eccles et al., 2003; Fredricks \& Eccles, 2005; Fredricks \& Eccles, 2006; Gadbois \& Bowker, 2007; Gilman et al., 2004; Guest \& Schneider, 2003). Limited research concerning high school theatre exists, and less of it explores elementary theatre (Beales \& Zemel, 1990; Button \& Millward, 2006; Cousins, 2000; Dumais, 2006; Farris \& Parke, 1993; Larson \& Brown, 2007; Pitts, 2007). Therefore, the present study concentrates on student perceptions of the residual effects of participation in a school sponsored children's theatre program and whether those effects align with the recurring themes in the current body of research literature. 


\section{Chapter Three: Methodology}

For this study, action research (Spaulding \& Falco, 2012) was conducted using an inductive approach and following a phenomenological qualitative protocol. The objective was to assess students' perceptions of the residual effects regarding their prior participation in an elementary children's theatre program. In order to achieve this objective, I interviewed 22 students who were 11-16 years old. They had previously held leading roles in any of the children's theatre plays during their elementary school tenure. Interviews were conducted in two waves over a three month span of time. As a culmination of the interview process, a focus group (Wilkinson, 1997) was held in which students could discuss various perceived lasting effects of participation in a school sponsored children's play. Interviews were conducted by two, third-party interviewers, and each interview lasted for approximately 20 minutes. The first wave (Firmin, 2006) of interviews was completed in two days, and the second wave of interviews was conducted approximately three months later. Ten students participated in the second wave of interviews.

\section{Rationale for the Method}

Phenomenological qualitative research is used to study participants' unique perspective of an event or an experience to determine the essence of that experience (Creswell, 2013; Johnson \& Christensen, 2004). The particular educational issue on which I focused was the residual effects of participation in a school sponsored elementary children's theatre program. A phenomenological research method was necessary in order to uncover the essence of these perceived effects of the students involved. 


\section{Population of the Study}

The population of the study consisted of 11-16 year old middle school, junior high, and high school students. The results of the study are most applicable to predominantly Caucasian students in a rural public school in the Midwest. Students in this study primarily came from homes of middle socioeconomic status.

\section{Sample}

Sample criteria and method of sampling. The adolescents chosen for this research were students who had held a "leading role" in an elementary children's theatre program. I operationally defined a leading role as having 15 or more lines in the school play. Parental permission was included for each student involved in the study. A purposive (Mertler \& Charles, 2008) sample was used for the study.

Rationale for the sample. The Plain City Elementary School's children's theatre program has been in existence since 2003 . Approximately 25 students annually participate in the program. At the time of the research, it was neither feasible nor practical to interview all of the approximately 100 students who had been involved in the program. Many of the original characters had significantly reduced speaking parts, and some had none at all. The students who participated in the program with significantly smaller parts did not attend the rehearsals every day and, therefore, potentially could have skewed the data. I chose the students with the most prominent speaking parts because they had participated in the program every day from the beginning of the audition process until the final performances. Thirty-one students met the assigned criteria. Every student who met the criteria of 15 or more speaking parts was sent a letter of invitation to participate in the study. Nine students did not participate due to relocation to another 
state following elementary school, lack of response, or inability to coordinate their schedule.

\section{Procedure}

Instruments. The instruments used for data collection involved handheld tape recorders, interviews, and a focus group. Two third-party adults interviewed the students to avoid researcher bias. One of the interviewers was assigned the role of group moderator for the focus group, enabling the discussion to stem from previous individual interviews. Standardized interview questions (Johnson, 2008) were prepared in advance around the major constructs of the perceived residual academic, personal, and social network effects (Appendix A). A second set of interview questions was prepared prior to the second wave of interviews (Appendix B).

Pilot study. The interview questions were reviewed by a select group of reviewers to clarify the organization and validity of the questions. Questions were then modified based on the comments of the reviewers (Leedy \& Ormrod, 2010). The first wave of interviews was conducted in four days. The students interviewed on the first day were a random sample based on the students' schedules. The information from the resulting interviews allowed me to make any modifications necessary for the subsequent interviews.

Data collection methods. The primary means of data collection was interviews, augmented by a focus group (Liamputtong, 2011; Wilkinson, 1997). In order to guard against researcher bias, two, third-party interviewers conducted one-on-one interviews following the interview guide approach (Appendix A). I completed the first wave of interviews in a one-week time period. Each interview lasted approximately 20 minutes. 
After coding the collected data, a second wave (Firmin, 2006) of interviews was conducted (Appendix B). Based on the quality and depth of the original interviews, I selected certain students to participate in the second wave of questioning. The emergent themes from the preceding interviews contributed to this selection process, as well. This second round of questioning occurred three months after the original interviews transpired.

The second set of data collection occurred through a focus group (McMillan, 2012). All students involved in the study were invited to participate in this peer group discussion. A pizza dinner was provided as incentive for participation. Although more students had intended to participate, a small group of five students actually attended the scheduled focus group event. The interview questions from the second wave of interviews were used as the interview protocol (Appendix B). The focus group lasted approximately one hour.

Relevant ethical considerations. This phenomenological study posed no risk to the participants. Interviews were conducted in a familiar setting and, as a district representative, I was present for all interviews as a safety measure. Each building principal whose students participated in the interviews was notified and gave informed consent to the study. My own building principal also was kept abreast of the research process and gave consent to the use school facilities to conduct the interviews. Each participant's parent or guardian was notified of the study, and they granted active informed consent, as well (Appendix C). Parents were informed that I would be supervising the interviews, taping, and transcribing them. Each participant also gave active assent to participate in the study. Parents and students were notified that 
confidentiality would be upheld throughout the research process. Pseudonyms were used in the written results, and I was the only person who knew the participants' true identity.

Methods of data analysis. I collected the data and coded it following Maxwell's (2005) open coding structure. This means I did not begin the coding process with a preset list of constructs that I arbitrarily sought to verify. Rather, I used an inductive process. Then, I assessed the codes for repeated words, phrases, and overall themes (Bereska, 2003; Lichtman, 2013) using constant comparison of the transcripts (Johnson \& Christensen, 2004). I had no presupposed themes in mind as I completed this process. Instead, I utilized reflexivity (Johnson \& Christensen, 2004) in order to guard against potential researcher bias in the study's results. Throughout this process, I also observed that saturation (Silverman, 2006) had occurred. In evaluating the transcripts, I was able to observe that the students repeatedly revealed similar themes. It was also clear that the students had no new data to share relative to the topic following the second interview wave and focus group participation.

I incorporated two methods as I assessed the codes. First, I removed potential themes that lacked sufficient support from the data (Fereday \& Muir-Cochrane, 2006). That is, some initial codes had been developed during the preliminary appraisal process. However, insufficient support was shown for all these particular codes. Therefore, the unsupported ones were discarded. Second, I combined several themes into similar constructs in order to format the results of the study in a clear and concise manner (Rubin \& Rubin, 1995). This allowed me to succinctly summarize the students' perceptions. Safeguards to internal and external validity. I incorporated several safeguards in order to maintain the internal validity of my findings. First, I had been the director of the 
plays, and I was instrumental in the creation of the children's theatre program. This posed potentially serious threats to the validity of the results (Salkind, 2009). Consequently, in order to protect against researcher bias, I utilized third-party interviewers (Kvale, 2007). This allowed the students to be free to share whatever their experiences were as a result of participation in the play. Third, I used low-inference descriptors in my results (Johnson, 1997). As much as possible, responses were written verbatim to accurately reflect students' feelings and experiences. Finally, I employed some triangulation (Patton, 2001), including two methods of data collection: interviews and a focus group.

Member checking (Mero-Jaffe, 2011) was another element utilized in order to enhance the study's internal validity. In accordance with typical qualitative research protocol, I revisited numerous participants and shared with them the results of the present study. They evidenced general agreement with the findings, indicating that the results aptly reflected the sentiments that the participants had related during the interviews. Another means of augmenting internal validity included the creation of a data trail (Rodgers, 2008). This involved generating an organizing structure where the supporting quotations for the themes reported in the present study were categorized. A data trail, sometimes referred to as a data audit, enables external reviewers to assess the data and double-checks to ensure that the findings are adequately supported in the participants' transcripts. Data trails also are useful for future researchers who may desire to replicate the present study or advance it further with future, additional samples. And finally, internal validity was enhanced by review from a qualitative researcher who was independent of the data collection and coding process (Cope, 2004). The robust nature of 
the present findings was supported through independent review, with the intent to help to ensure that my own biases as a researcher were kept to a reasonable minimum.

There were limitations to the external validity of this study. Due to the nature of sampling and the limited scope of the study as action research, the results of the study cannot be generalized to a universal population (Hendricks, 2009). However, the most effective way to achieve external validity in qualitative research is by repeating the study in various settings (Raffanti, 2007). The goal of this particular study was to determine the potential residual effects of participation in a specific elementary school's theatre program, as they were perceived by the leading performers. As such, the study can provide valuable data, potentially contributing to the overall literature of extracurricular activities and theatre-integration in classroom settings. As future researchers incorporate the findings of the present study into the results of other qualitative studies, using other samples, external validity eventually will emerge. That is, researchers will be able to tell how the present findings elucidate the overall picture or understanding of elementary school drama participation (Miller, 2008). 


\section{Chapter Four: Qualitative Analysis}

I analyzed the data from students' transcripts regarding their perceptions of the residual effects from participating in a school sponsored elementary theatre program. Each student held a leading role in at least one of the children's plays during his or her elementary school tenure. The children's theatre plays were modified fairy tales or other popular children's stories, including Snow White and the Seven Dwarfs, The Wizard of Oz, Alice in Wonderland and Peter Pan. Participation in the program included school auditions, daily rehearsals, and two final performances: a school assembly and an evening performance. The entirety of each program lasted approximately one month's time. In keeping with a typical drama production, students' names were included in a printed program which was distributed prior to the final evening performance, and students dressed up in costumes for their assigned roles. Overall, student perceptions of residual effects aligned with previous research results in multiple ways. Findings from the present study include academic effects, personal effects, and social effects. Students also described experiencing a connection to the theatre as a result of their participation in the theatre program.

Academic Effects

Memorization. Most students interviewed in the study reported improved memorization skills as one of the academic carry-over effects of having been in the 
school play. Naturally, middle and high school students continue to develop metacognition abilities, and participants noted varying levels of self-awareness in this regard. Nonetheless, there was a resounding sentiment that memorizing skills learned during earlier play practices helped to improve future academic memorizing. Some participants related specific memorization techniques they learned during the duration of the plays. For example, Mia reported, "It [participation in the play] helped me memorize like if I just read it over and over." Sophia shared a more advanced understanding when she discussed highlighting important parts as another memorization technique:

I learned how to, like, go through and memorize lines, and when I was studying for tests, I would highlight certain things I needed to know, and I would remember that. And that, for a fourth grader to remember that, that's pretty big... especially a fourth grader like me.

Others mentioned memorization elements that research has shown to be associated with brain lateralization, such as the use of music. As an example, Ella stated: "I memorize stuff by song now, because I do my lines over and over again and like make a song up to them. And I also just go over and over and over again."

Students also conveyed that memorization skills enabled them to retain content in various school-related subjects. That is, their participation not only aided the memorization process, involvement with plays also supported their efforts to learn subject-specific content. As an example, Ella stated: "I'm a lot better at memorizing, especially math facts." Similarly, Ryan added: “The academic math bee, spelling bee, geography bee. It's [participation in the play] affected that academically." Tests and quizzes were two domains where participants indicated a belief that memorizing for 
school plays helped them memorize better in other academic subjects. They believed that the skill sets learned early in their academic experience had a generalization effect on later learning abilities. Alexis boasted: "I'm like really good at remembering vocab words on tests, and remembering my lines and that kind of stuff." Logan also stated his belief that memorizing lines provided success for spelling tests: "Cause we've had to do more things, now we're doing spelling tests, where you kind of have to memorized the words more...it's helped memorize them more, I think."

Memorizing required speeches is another domain frequently mentioned by students who participated in the study. They expressed general sentiments that their previous practice with memorizing for school plays aided future memorization when they were required to make class oral presentations. For example Maya claimed that "I can memorize my speeches faster." Addison believed that using the memorization techniques learned from school plays enabled her to demonstrate improvement in her public speaking skills. Evidently, some of the earlier trial and error attempts (from play practice) helped to winnow the range of options for students later - since they now have better conceptions of what works and tends not to work for respective students. Aiden illustrated: "Like for the memorization, I've used it for speeches again. So I could...I wouldn't have to keep on using my note cards or whatever so I could have good eye contact."

Public Speaking Skills. The ability to deliver better speeches was a second residual effect of participation in a children's theatre play noted by most of the study's participants. Development of effective public speaking skills is a learning objective of most school curricula, and students in the present study cited their previous play 
experiences as undergirding what they later learned in other classes. For example, Jack specified the academic nature of these speeches: "Well, I use them [skills learned from play experiences] for speeches in fifth and sixth grade, and for poems when I was in elementary." Similarly, both Gianna and Abigail remarked that they were able to use public speaking skills they learned from play participation when they later gave reports in front of their class at school. Jada likewise shared that she used public speaking skills as part of her role in middle school as the person who gave the morning announcements.

Another skill related to speaking in public is that of connecting with others. It can be a challenging art to learn - for people at any age. Some skill development in this area was related by individuals such as Lily when she stated: "I was a top gun in DARE, so I really needed to... say my stuff...like I meant it. And...I had to, like, make eye contact with the audience and stuff and move toward them, like that kind of thing."

Many of the students listed specific features of good public speaking skills that they learned from participation in the elementary plays. They believed that a carry-over effect occurred, long after the participation in the play had ended. For example, Evelyn said:

And when you talk in front of your classmates and they're all staring at you, wondering what you're gonna say next, it's like if you think back to the play, you have to speak loud, speak slowly, so they understood you and make sure that you were saying the words right.

Most of the study's participants identified the ability to project their voices as a salient component of good public speaking they learned through participation in the play. Another common reference was enunciation or, in Ethan and Chloe's words: "saying 
things clearly." Dramatic inflection was said to be a third facet of public speaking commonly noted by the students in the study. Naturally, they did not use this phrase in the interviews, but communicated the notion in a variety of ways. Students consistently spoke of trying to avoid monotone when communicating to groups. As examples, Julian discussed having "excitement" during different parts of his speech, Adriana stated that she had "a little bit more drama in my voice," and Neveah said, "Sometimes I have more drama and stuff in my voice."

Personal Effects

Self Confidence. One of the major constructs from the interview process was the residual effect of self-confidence. Confidence to speak in front of groups often is generated through experience. As such, it is a difficult construct to be taught only through book knowledge or lectures. Performance on stage seemingly helped to bolster students' later confidence in class through their positively reinforced experiences. While many of the students succinctly stated that they had improved confidence as a result of participating in the play, perhaps Jayden stated the idea the most crisply:

I think it kind of made me more confident about myself, like knowing that I've achieved something, like, if I got the part or something. And I guess it just kind of made me more confident for just doing whatever in school and life.

Data from students' interviews showed subsets within the larger, over-arching theme of self-confidence. One subset was that of having confidence in the face of potential failure. For example, Olivia stated that a benefit from the play was that she learned "to just go ahead and try out for something, you never know if you're gonna make it or not." Fear of failure is a natural, developmental emotion, experienced by 
students at all ages. However, previous involvements with the play seemed to have a buffering effect, of sorts, for students in the sample in this regard. Grace stated: "Like, it gave me more confidence, and I just felt you had to do your best and if you didn't, oh well." The participants did not say in the interviews that fear went away or they never experienced anxiety. Rather, their experience with play involvement was said to help provide a counter-factor that helped either keep fear in check or compensated for anxiety to over-ride it at times. For example, in regards to the audition process relating to potential failure, Steven stated: "I learned how to...go out and put yourself out there even if you can't always make it, it's just fun to try."

Second, participants in the study revealed another confidence subset via an existential, bolstered sense of confidence in whom they are as individuals. Obviously, all teens are finding their own respective ways in life, and involvement in plays was not said to be the panacea for "finding themselves." Nonetheless, enhanced self-awareness occurred through the process. Rebecca said that she learned "to...be who, like, I am and my character, not just hide." Self-insight is a valuable construct and can be cogent when young people begin to achieve it. Gabrielle said that participation in the play taught her a valuable lesson about herself:

"I learned that...I wasn't that scared of being in front of people... You know, before the plays, I was completely nervous. I'm like, 'Is everybody gonna hate me or something?' and I just learned to really be myself, and...that I really was pretty good at speaking in front of people, and I was really comfortable doing that." 
The students universally stated that the self-insight they received from being in the play was positive. That is, they believe what they learned about themselves contributed positively to how their self-esteem had developed up to the point when the interviews were conducted. For example, Ava stated that participation in the audition process taught her to exercise greater levels of transparency, "showing them, like, who I am." Micah learned that "I enjoy speaking. Being in front of a crowd...when I have like this solo, speaking over a long part, you get center of the stage, everyone's looking at you. I guess I like that feeling.”

A third confidence subset for students involved having more confidence in the area of making social connections. Like most participants in the study, Jocelyn said that acting has really helped her to make new friends. Students did not tell the interviewers that they necessarily became popular among their peers or that they were the most popular in their respective classes. Rather, they felt an enriched sense of social connection. As an example, Lily participated in the play when she was in third grade. She stated that participation in the play helped her align satisfying social networks:

I became more social, because... I was more like, the kid in the corner. Didn't really want to hang out with anyone. And then, once I did the school play...I started branching out more.

Similarly, Will said that participation in the play allowed him to embolden his confidence "to meet new people, instead of, like, hanging back."

Fourth, students revealed that participation in the play also resulted in enhanced self-confidence to be on stage in spite of potential opposition or negative feedback from other people. Developmentally, young people are hard-wired to eschew rejection. 
However, previous participation in the school play seemed to provide some psychological resiliency to becoming overwhelmed or captured by these natural tendencies. Katie shared sentiments of many in the study when she stated that, if someone told her she did a poor job in the play, she would say something as, "Oh, well, I still did it. And I like that kind of thing." Similarly, Emma said the play benefited her life in the same way: "I can be whatever I want to be... it doesn't matter what your friends do. It doesn't matter what they think. If you want to do what you wanna do, then do it." The students in the study spoke in terms of taking ownership of their performance, irrespective of what others later said or thought. This type of perspective seemingly facilitated a healthy confidence development. For instance, concerning potential criticism from others, Bryce said, "I've made sure I wasn't really ashamed of what I'd done. Cause...there's always going to be someone to criticize you, but you gotta be proud of what you do."

A fifth subset of confidence development reported by students was that their selfefficacy was improved as a result of positive feedback from adults and their peers. Similar to most participants, Ashlyn stated: "And then, after I got like a bunch of 'good jobs,' 'you looked really good,' I was more confident with myself because people were like, congratulating me." Students did not speak in terms of feeing haughty about their performance; they conveyed a reasonable degree of humility. Nonetheless, there was a healthy sense of pride in terms of feeling affirmed by others. For example, Rachel shared her reactions to positive feedback during the play:

Well, like, whenever that happens, it just like makes me feel really good. Just like, when someone just comes up and randomly says good job about the play or whatever. It just makes my day better, because it's like, 'Oh, well, thanks.' 
McKenna mused about the effect that the applause from the audience at the end of the play had when she said:

And you get done and then they're all cheering. And then they're up and then they're standing and like they're just having a great time and stuff. And then that, like, boosted my confidence so much to say, like, I can do it. And it's not embarrassing, it's just for fun. And so that really boosted my confidence. As noted earlier, students reported that they received both positive and negative feedback from their performances in the play production. However, the positive ones seemingly overshadowed the negative - at least retrospectively, in how the students currently recall the over-riding effects. Most students, like Gracie, agreed that selfconfidence increased due to positive feedback:

It [being in the play] did increase my confidence because, like, you aren't all nervous in the beginning and then you realize, well, these... are your family or your friends watching you and they'll support you. And it's just like great to get compliments at the end.

Caroline described her own experience in perhaps the most notable manner as she discussed the relationship between self-confidence and coming back to class after performing in the school-wide assembly: "And I really liked the first play, because once we came back into the classroom, all the classmates started asking for autographs and that really got my confidence up."

Finally, students believed that their self-confidence increased as a result of satisfaction received in the finished product of the children's plays. For example, Peyton recalled his sense of pride in having completed the school play in such a short period of 
time. He said: "We would know what to do, and I always thought it was kind of cool how just in a couple months or weeks or so, we could put together something that turned out so well." Similarly, Henry illustrated: "It was...kind of cool to be able to get up in front of everybody and kind of share what we'd been working. I learned that you should be proud of what you've done and be able to share it with others." This sense of accomplishment at the completion of the production seemed to cause students to become cognizant of their capabilities, thus strengthening their confidence in these abilities. For example, Dominic said: "I was able to [go] up in front of a lot of people, the entire school and their parents, and be able to perform the part I had been given and know that I did a good job." One component of a play that defines its completion is the curtain call. Although the students did not refer to the curtain call by name, they did describe the effect it had on their confidence as they took their final bows together. This moment of a play in which camaraderie meets external approval resonated with the students and further increased their self-confidence. Xavier described how the final bow affected his confidence:

I do think that...just the group bows at the end of the plays all kind of boosted my confidence a little bit. Because we'd all be standing there together, there was a kind of a feeling of togetherness that you had when you were up there. And it really made you think about how all of you had worked together to accomplish something piece by piece. Put it all together and make it a masterpiece at the end. Overcoming Fears. Students also relayed that participation in the play affected how they dealt with their fears. The initial audition process is one element of a play that can increase student fear. Often, society views stressful situations for elementary 
students, such as auditions, in a negative light because of the emotional stress and anxiety it may cause them. However, involvement in tryouts can allow students to experience this anxiety in a controlled environment so that they learn how to work through it in a healthy manner. As an example, Victor stated that auditioning for the play helped him to overcome his fears: "You were nervous because you wanna do well. But you have to just let yourself do as well as possible without letting your nerves get in your way."

Performing the play for an audience also can increase student anxiety. Although the idea of acting onstage in front of students' family and friends was deemed to be a root of their fear, students seemed to find catharsis via the performance itself. For many of the students, their anxiety dissipated when they stepped onto the stage and recited their lines. The reality of performing overcame their fear of the audience. For example, Leo said: "You know, like, when you first step out there's the initial, 'Oh me! A lot of people out here.' But then...that only lasts five seconds once you get absorbed in what you're saying in the play and it just goes away pretty easily." Everett also discussed how quickly his fears subsided during his first play: "So, I was kind of nervous, but then you get up there and you just kind of get all those feelings and it's not quite as hard as you think it's gonna be."

While students' immediate fears dissolved after they successfully began the play, the success of having performed the play seemed to diminish students' performance anxiety in the future. That is, having performed a play in elementary school, students seemed to have less fear regarding subsequent opportunities to perform or speak in front of an audience. For example, Vivienne shared the sentiments of most students when she stated: 
I wasn't really that good of an actress because I was kind of afraid of being in front of people and everything. But after I've been in different plays, I've been able to act in front of people and not be as scared of like what they think and stuff. Similarly, Cora talked about the very first play she did in the children's theatre program: The...play was the first time I ever got in front of people and talked....And so, um, I went up there and like I'm scared to death. But then...I didn't forget any of my lines and I just, I haven't been really scared since that.

Sometimes, success begets success. This principle tended to be true for students in this study. Max agreed: "I was afraid to go out onstage at that time. But like, now I really am a lot better with that and I have no fear at all. And I enjoy it a lot more, like talking in front of people."

Making mistakes. Participants in the study also reported what they learned about making mistakes. Sometimes, students tend to view errors as a failure, not a learning experience. Through participation in the play, however, students were able to see that everyone makes mistakes. Furthermore, they realized that it can be acceptable to do so; errors are a normal part of their life experiences. Austin aptly said: "I think it kind of made me realize that making mistakes is OK, and like, everybody makes them and stuff." Students often described themselves as pushing forward toward their later academic goals - despite some setbacks. Their early experiences with the school play were said to have been positive contributors to that end. For instance, another student, Cooper spoke of his experiences with mistakes that were made during performances: "It's OK if you make mistake[s], 'cause we would go through it. And we'd mess up a line or something and it 
would be OK, we'd just keep on moving on. It doesn't really matter. Everyone makes mistakes."

More than just enabling students to realize that mistakes happen, participation in the play reportedly allowed them to learn specific adaptive techniques when a mistake occurred. Some of the participants recalled the strategies they used to resolve the mistakes that were made onstage. First, Arabella said: "It doesn't matter, just keep on going. Cause otherwise, if you don't go on, the thing falls apart." Elyse agreed with this strategy:

Well, like in the play, if you make a mistake, you gotta move on...if your friend is like standing right beside you and your line is right after hers and she messes up or forgets a line, you just gotta go with it. If there's a pause, say your line, just skip her line and move on. Cause you want to keep the play going. So, if you make a mistake, I guess you just keep going. Just forget about it.

A healthy sense of resiliency evolved, and this was said to have generalized to other, later life domains as stated by another student, Ivy, who learned that "you just go back and do it...if you forget, just make it up."

Students also had the opportunity to correct their mistakes because they had two performances. If mistakes were made during the first performance, students potentially could correct those mistakes during the public performance. This allowed them to absolve their original errors, which seemed to complete the learning process of making a mistake, working through it, and resolving to change future behaviors in order to prevent the same mistake from happening again. Naomi recalled a specific instance in which a mistake was made and how the cast dealt with that mistake, as well as how they corrected 
the mistake for the second performance. This was a skill that reportedly later became part of her life repertoire. She stated:

The second one I did...I think we messed up our lines. Like, we totally missed an act. And like, I don't know whose fault it was. I think I might have said the wrong line or somebody else, and then it got other people involved with the wrong lines and stuff. So, we ended up totally missing an act... and it was good because it wasn't like we missed a whole big thing, but we all made the mistake that we missed the act. And then, um, the next time... we did it for everybody else and like the parents, and then we made sure the mistake wasn't made again.

Practicing. Students also reported that participation in the school play taught them about practice, an important life skill. Many of the students reflected on the benefit of practice. They found that performing the play and their understanding of the characters improved due to repeated practice. For example, Noah said: "It's easier once you like practice...it's just easier how to do stuff." Seth agreed, "I knew that practicing helps, I just found out that practicing boosts my performance.” Students consistently remarked that they carried-over the construct of practice effects to other areas of academic learning. As an example, John commented: "I think you have to practice a lot. Like practice makes perfect. That saying kind of applies. "

Students recalled the importance of learning their lines for the play, specifically how memorizing the script required intensive practice. They learned that, in order to be successful, they needed to avoid procrastination and utilize their time prudently, both at school and at home. Delilah encapsulated the sentiments of most students regarding indolence: "You can't procrastinate when you're doing it. You can't learn it till the last 
day before the play. You have to be doing it and doing it and doing it." Repeatedly, students remarked that procrastination during life-in-general would lead to eventual trouble. This was a concept that evidently first became most clear regarding the importance of practice. Archer stated: "Well, you know you had to practice the play. You had to get it out and practice it. Come to the play practices, practice it at home. Recite it in front of the mirror. Get your facial expressions; say it in front of your parents and all of them." Aaliyah discussed the importance of practice as well, focusing on the effect of not practicing on the production: "I practice a whole lot on my lines...you need to have them down and if you don't you could ruin the play for everybody else and get everybody on different lines and confused and mixed up." This exercise of character was said to be an element that students believed contributed to their respective current academic success.

Working hard. Students also discussed the importance of hard work. They found that they had to resolve themselves mentally in order to complete the task before them. Often this mental resolve was connected to the memorization of their lines or the analysis of the characters. This recognition of their determination to focus on a task until its completion potentially was said to have had long-lasting benefits for the students. Having recognized their fortitude through participation in the play, students said that they were better able to exercise the same strength of will as they now complete new tasks and assignments in the future. For instance, Ezra stated:

In my first play...I learned about working hard...Because a lot of times, I would need to have to tell myself to practice my lines, even though I didn't always want to. But, then I'd have to, just so I could get through crunch time to be able to 
finish the play. And so, that kind of helped me be more self-motivated to do things.

Adrian also noted that it was important to work on memorizing lines outside of practice. He said: "And I got the script and you know you have to work hard to get that and get your lines to where you want it to be. And you know, you have to be determined to get that done." Regarding the relationship between plays and hard work, as well as its application to the future, Hunter reported: "Well, plays are usually a lot of hard work, like practice and practice. And I think that helped me realize that nothing really comes easy. It's not just gonna come to you, you have to work at it and practice."

Taking responsibility. Students also discussed that they learned about being responsible through participation in the children's plays, particularly in the area of memorizing their lines. They reported being more cognizant that accomplishing such a task required a certain amount of self-discipline and motivation. For instance, Louisa said: "It really helped me being responsible and working on my lines and working on...how I express my lines and stuff. And it helped me with being responsible and getting down what I need to get done.” From a developmental perspective, learning responsibility is a key task (Feldman, 2009). Participation in plays was said to have contributed positively to students' character development in this regard. Bennett shared perspectives similar to most, saying how he believed responsibility related to procrastination. He said: "They'd say you have to memorize your lines by this date, or else, like, we'll be behind and it wouldn't be good. So, it kind of showed me to get things done on time, and not to procrastinate or anything." 
Students most often reported being able to transfer the lessons learned regarding responsibility to other areas of their lives. This understanding seemed to be categorized in two ways. First, students linked responsibility as an essential component of being mature. One of the oldest students in the study, Sophia, explicitly related responsibility to development toward adulthood. She stated: "It's being mature and acting grown up and learning to take responsibility for my actions. And learn how to just be a mature, young adult." Second, students indicated that they transferred their understanding of responsibility to its use in other aspects of their lives. Similar to other students, Colton said:

I need to have everything ready and I need to know exactly what I'm gonna be doing. And that kind of applied to other things in life, like school work. I have to have my homework done on time. Soccer practice, I have to have everything, I have to be there on time, do all the drills on time, everything.

Students' early experiences with play practice were said to have been formative. That is, the practices provided learning experiences in character development. As students appraised their current levels of diligence, they indicated an ability to connect those levels back towards lessons learned during rehearsals.

\section{Social Effects}

Teamwork. Participants of the study believed that involvement in the play positively affected their later ability to work as members of a team. They reported learning that part of teamwork involved listening to the views of others and compromising in order to complete tasks or solve problems. Students discussed the need 
to listen to everyone's viewpoints in order to solve problems or make plans. For instance, Silas said:

You have to kind of take other people's ideas and use them with the play. You can't just always do what you want to do, or what the directors want to do. You kind of have to discuss what everybody wants, in their plans for the play.

The art of negotiation and compromise often is a requisite for life vocational success. Students indicated that their play practices helped them understand the essence of this concept. Ruby spoke for most in the participant group:

You learn to work with others. You can't just stick to your idea, you learn to like talk to others. And if there's a problem, you have to learn to work it out. Cause you have to try to still put on a good performance.

Students believed that a cooperative environment in which teamwork occurs promoted a sense of community. Students reported experiencing the ability to work through disagreements and problems, as well as helping each other through difficulties as an essential component of this community dynamic. When these skills were utilized, students seemed to feel as though they were connected in a more meaningful way. For example, Rosalie described one of the plays and how they worked together as a team: There was...14 or 15 people on the cast...So...we all worked together and like if somebody forgot a line or something, like we'd back each other up. Or if somebody, like, didn't get something perfect, we'd help somebody. And like a lot of people helped me, and like everybody was just helping each other. So we were like one big family. 
Developmentally, teenagers have a natural bent toward self-centeredness (Bergen, 2008). Obviously, previous participation in plays did not eradicate these tendencies. However, it did help to provide a broader perspective for the students in the sample, allowing them to be able to see beyond themselves at times. For example, Sawyer related the sentiments of most participants when stating:

I definitely learned that working with a team is... a very valuable thing to be able to do. Um, when we were in the plays, at rehearsals, we would definitely have to work together to kind of get through crunch time. And, we would have to all work together because we'd have to listen to each other's cues, try to remember our lines and sometimes try to remember other people's lines. And so, we all just kind of had to, even if we didn't like each other all that much, be a big family, to get everything done.

Positive Social Networks. Students reported a positive connection to the director of the children's plays, principal, and school teachers who did not assist with the productions. Many of the students felt a particular special bond with the director of the plays. For instance, Eleanor stated: "You have, like a bigger connection to them. Like, you understood them more." Also, the participants felt more at ease with the director and developed a greater respect for her due to seeing her work on the play. Quinn related the sentiments of most students: "Yeah, I think that whoever you're doing the play with, you become closer to them and like, you're more relaxed when you're around those teachers." Aaron discussed the close connection to the director, as well: "I felt a lot closer to the teachers, like the director, and I respected them more, seeing how hard they worked and everything." One likely reason for the bond was that the director's personality traits 
became more apparent as well as her personal theatre and life experiences, allowing students to view her as a "person," not just a "teacher" in the school. For instance, Zoe recalled: "They'll start telling you a story and you can relate to them better." Finn talked about how the teachers were less inhibitive, as well: "You kind of get to see the other sides of teachers, 'cause...there's not everyone around them, so they can kind of be theirselves, too.”

The knowledge of and the connection to the teacher appears to be cyclical. That is, as the students came to know the director, they felt more connected to her. The students most remembered the encouragement that the director provided throughout the course of the play. This support seemed to deepen a positive connection to her. For example, Avery said: "She kept on giving me the encouragement that I needed to keep on going and going. Especially the note before Alice in Wonderland and the cookies and stuff. That really encouraged me." Jovan concisely summed up both the connection and the encouragement:

I felt more connected with [the play director] during and after the plays...she honestly wanted us to be able to do better and to accomplish what we wanted to achieve, especially the younger people like me in the first play when...she could tell we were kind of nervous. We didn't know exactly what we were doing, but she helped us. Told us what we needed to hear and got us through.

Students also reported a different type of connection to the school principal. Many elementary students previously viewed the principal as a disciplinarian, which can naturally lead to a sense of unease. The play seemed to provide a topic of conversation between the students and their principal. Apparently, students felt more connected to her 
due to conversations during school and afterwards, at practices, and they and were able to view her differently, as a result. For instance, Jerry said: "I felt more comfortable around them. Like, I didn't say, 'Oh, gosh, that's the principal!' I felt more, like, you know...you joke around more, know "em better." Also referring to the connection to the principal, Lela said:

I've had a lot more respect for them. Like I see them more as a normal person, too...Because before, I was like, 'Oh, it's the principal, be on your best behavior.' But now, I see them, like, 'Hey! It's the principal, what's up?'

Participants also reported that they were able to converse more easily with other teachers in the school due to participation in the play. Students found that after teachers had seen the school play, they would encourage the students by giving the participants compliments about the show. The play became a catalyst for student and teacher conversations. Lina illustrated: "They...would say good job, and we'd get into a conversation, and then, um, we'd have a really good time." These personal involvements provided natural opportunities for teachers and students to link in positive ways. The carry-over effects for students - long after the play was finished - deepened. Robyn shared the sentiments of most: "I talked more with the teachers and had more fun with them," and similarly, Clay stated: "In classes afterwards and stuff, the teachers would...often kind of, just have conversations with you about the play. It brought up conversation subjects and things like that."

Peer Social Networks. The students continuously discussed the positive peernetworks that were created due to participation in the play. Some participants tried out for a school play in order to spend time with their original group of friends; however, 
others shared how they were able to meet new friends. For example, Kirk stated: "I think like, whoever was...in the play with you, your friends in the cast, I think you become closer to them and you just know more about them." Elementary school tends to be different from high school in that it is more compartmentalized by grade-level. Third graders spend time with third graders, fourth graders spend time with fourth graders, and so forth. The play seemed to build friendships across that grade level divide. In Caleb's words: "In the play, there were...people that you know, like, they'd be in different classes and we wouldn't know them very well. And, because of the play, you'd get to know them." Often, these friendships were said to have continued beyond the play's production. A type of camaraderie was said to have developed among the cast. Jude exemplified: "'Cause I was in the third grade and didn't really know anyone in the grades above, so when we'd do the plays, I'd get to know them. And I'm still friends with a bunch of them now."

Participants shared that the play provided a common interest among new friends. Students were able to connect with people who shared similar interests and skill-sets. For example, Billy stated that rehearsals really gave me a chance to connect with teachers and my peers that were also in the play, because we all shared a common interest there. Everyone there liked acting, liked performing, and liked speaking in front of others. So, we were able to connect on some level with that.

Also, Roxy felt like she was able to make new friends "'cause we know at least one thing we have in common." This connection was viewed as an outlet from other peers with whom students were typically friends. That is, most often, none of their "everyday" 
friends had an interest in theatre, but the new friends in the play shared that interest. In this respect, participation in the plays tended to enhance students overall school experiences. The new friendships helped students broaden their social networks, providing exposure to a larger population of social networks. Marian illustrated the sentiments of most:

Oh, it's really fun working with different people, because...not a lot of my friends are into acting and stuff, so I get to meet a bunch of new people and we get to work together to come up with good ideas for the play and make it really good. Love of the theatre. Participants consistently shared a continued love of the theatre and acting, as well as a desire to participate in more plays, later in their educational trek. Because the play often was the first real experience that students had on stage, they were able to realize an interest in something new. Anita said, "It's been, like, a great experience. I mean, I keep doing plays. Like, I just love acting." Having an initial experience that was positively reinforced helped foster a latent talent that participants indicated. Anthony illustrated this point: "I think it's really fun, and I never really knew what acting was, but then I realized I was good at it. And it's given me something to do in my free time, instead of like, sitting around and watching TV." Due to their new-found interest in theatre, many of the students decided to participate in future plays as they grew up. For example, Reuben shared that "being in plays makes me want to do more and more with acting, just as I go down the road." The initial participation in acting gave students a small taste of what they were capable. They enjoyed the taste and wanted more of it. Julia related: "Yeah, I loved it so much when I first started doing plays, and I just wanted to keep on going." Having decided to participate in more plays, 
many of the students have auditioned for and performed in plays and other theatre activities since the elementary productions. For example, Wayne said, "I've been in two other plays since then and I enjoy the overall experience of them." Brian, in particular, shared that his experiences with the elementary plays led him to attend an acting camp.

Summary

This study revealed students' perceptions of the effects of participation in an elementary school play. Students revealed a love of theatre and a desire to continue along that extracurricular path. The perceived residual effects of participation in an elementary children's theatre program were increased academic, personal and social skills, including positive social networks. Additionally, students reported the transferability of specific academic and personal skills to domains outside of the performing arts. 
Chapter Five: Discussion and Implications

The purpose of this study was to examine adolescents' perceptions of the residual effects of participation in a school sponsored elementary program. It is clear that students believe that their experiences with a school-sponsored theatre program positively affected them in the years following their participation in the elementary plays. The students revealed specific academically-related skills that they believed were positively influenced as a result of participating in the school plays. They also believed themselves to have a greater sense of self-confidence and an increased measure of personal life-skills due to participation in the play. Furthermore, the students revealed a greater sense of connection to various members of the school community. Within the framework of previous literature, this study's results endorse future development of school sponsored elementary programs. Additionally, it provides a foundation for future research in the field of extracurricular activities as they relate to elementary school students.

\section{Interpretation of the Results}

This present study focused on the perceived effects of participation in a schoolsponsored elementary children's theatre program. The overarching theme of the study related to the enhanced academic, verbal, and social abilities garnered by students involved in the plays. These included increased memorization skills, improved public speaking skills, and developed social networks. Upon analyzing these enhanced abilities, it is apparent that there are five main interpretations regarding the results of the study. 
Improvement of specific academic related skills. First, in this research study, students revealed that participation in the school play enhanced both their ability to memorize information effectively as well as their public speaking abilities. These skills are promoted by school curricula as students progress through a public school system. In fact, some school districts are moving to a framework in which students must complete a senior project as part of graduation requirements (Dotson \& Grimes, 2010). The project typically requires students to formally present their findings relating to a project based on their academic interests. As a specific example, the state of Ohio Department of Education recently adopted the Common Core Standards ("Revised Academic Content Standards, "2012) which includes an expectation for adolescents to develop and utilize speaking and listening skills that are necessary for formal presentations. By engaging these academic related skills at a relatively early age, through involvement in a children's theatre program, students are at an advantage for increased success in school.

Set a positive trajectory for future utilization of enhanced verbal abilities.

Second, students involved in the present study specifically reported learning skills such as speaking loudly and clearly. Following the previously noted example in Ohio, based on the recently approved Common Core Standards ("Revised," 2012), students are expected to utilize public speaking skills as one component of their education. For instance, beginning in kindergarten, students are expected to tell a story in class audibly. By third grade, they are expected to present information audibly and use appropriate pacing. In middle school, students are expected to maintain eye contact, speaking clearly with appropriate volume. Because these skills are an intrinsic part of the educational standards, development of an elementary theatre program is apropos for curriculum 
enhancement. Such a program provides a resource for the educational community to set a positive trajectory for students' success in utilizing enhanced verbal abilities, such as memorization and public speaking skills. Students are able to garner early positive experience in these prior to official academic assessment. Participation in an elementary theatre program can allow students to more adequately meet these standards throughout their educational careers.

Create a primacy effect. Third, participation in the plays seemed to create a primacy effect. This is a longstanding principle in social psychology (Deese, 1957) whereby the first exposure to a received stimulus is given substantial weight by the recipient. In the present context, students seemed to have found their initial exposure to theatre to be particularly cogent (Feldman, 2001). In particular, students revealed a positive first impression of the theatre and also public speaking. Students also reported that they developed useful life and social skills through their participation in the plays. Sustained participation in theatre over time can allow students to continue developing these skills. Therefore, through an initial first impression of the theatre and public speaking via an elementary extracurricular program, a lasting impression can take effect and may be beneficial in developing useful social and life skills

Success begets success. Fourth, the students in this present study discussed their sense of pride in completing the play and feeling a sense of accomplishment at the end of the program. This healthy sense of pride and accomplishment seemed to motivate the students to try other theatre activities and programs, as well as attempt other future endeavors because they had been relatively successful in the elementary play. Many of the students continued to participate in children's plays and other public speaking 
opportunities. It would seem that, in this sense, success begets success. That is, early success in the elementary theatre program tended to cause a domino effect leading to future success and accomplishment.

Elementary plays are worth funding. Fifth, the students reported numerous positive effects relating to participation in the school play. Many of these effects related to enhanced verbal abilities and social skills. These abilities and skills are foundational to success throughout the schooling process. Therefore, the positive outcomes relating to participation in a school-funded elementary theatre program bolster the belief that elementary plays are worth the resources invested in the endeavors. That is, it behooves the leaders of a school district to provide monetary assistance in order to develop the most effective elementary theatre programs possible.

Potential Applications of the Findings.

In education, students are presented with a plethora of activities and programs designed to enhance their overall growth and development. However, too much involvement in these programs can cause students undue stress and anxiety (Brown, Nobiling, Teufel, \& Birch, 2011). Educational professionals therefore should review the potential outcomes of each program in order to determine its influence on the students who are involved. This process allows school districts to ordinally appropriate funding to the most beneficial programs and enhanced learning opportunities for adolescents. It also allows programs to be designed more effectively to promote students' positive development in academic and life skills. Based on the findings of this study, there are three relevant applications for educators and school districts. 
Devote adequate attention to the design of an elementary theatre program. The first relevant application for the present study stems from the primacy effect. Because students' first experiences with theatre and public speaking were seemingly positive, they shared a continued desire to participate in activities utilizing these components. Students generally expressed gratitude for the elementary plays because they believed that their early experiences in the theatre program in elementary school were a catalyst for their continued involvement in theatre and public speaking. Because the first experience with theatre and public speaking seems so impactful, it is crucial for teachers and school district leaders to devote apt attention to the design of the programs. One component of a successful children's theatre program should involve careful study and application of developmental psychology so that the program will positively impact students as they address issues such as overcoming fears and managing anxiety. Another aspect of a successfully designed program involves careful selection of the script. It should be written for children actors; that is, the children should be able to understand the characters and their motivations. Also, the themes of the story should be relevant to the young people involved in the play. This is important because children are most influenced by literature that is selected based on their development (Dwyer \& Neuman, 2008).

Incorporate opportunities for future interactions. Participation in the elementary plays seemed to create social connections between peers and teachers, alike. However, the span of time in which students are involved with a play's production is relatively short. In order to cultivate positive relationships between peers, and also between students and staff over time, teachers should create deliberate opportunities for follow-up 
through scheduled interactions. For instance, reunion parties for cast members might be scheduled, say every two years, in order for students to reconnect and reflect on their experiences. These scheduled reunions may also foster continued meaningful connections between the students as they interact with each other. Furthermore, teachers spearheading the elementary theatre programs may become student mentors over time. This can promote increased school engagement (Klem \& Connell, 2004).

Provide funding for continued theatre programs. Students revealed many positive effects from participation in the play, including increased public speaking skills, enhanced social skills and improved self-confidence. Many of these skills will be assessed over the course of their academic careers. Therefore, it is beneficial for a school district to continue funding the elementary children's program. Moreover, because students revealed an increased interest in future participation in theatre and public speaking, it would also benefit a school district to develop and maintain a theatre program district-wide. Additional programs in both middle school and junior high school will enable students to maintain the skills learned as part of the elementary program and potentially can continue to improve those skills as students mature. These additional programs serve as a transition from students' initial theatre experiences in elementary to the traditional high school theatre experiences typically in place.

\section{Biblical Integration}

Biblical truth is embedded into research of a children's theatre program. God devoted an entire book of the Bible to one man's quest in search of truth in the world around him. In Ecclesiastes 1:3, Solomon said, "I devoted myself to search for understanding and to explore by wisdom everything being done in the world." The 
wisest man on earth set out to understand the world around him and find wisdom and truth in it. This biblical example of research demonstrates the importance of assessing our own smaller worlds for wisdom and truth, just as Solomon did more globally. As a Christian in the world of education, I need to research each aspect of my work responsibilities in order to determine how I need to approach those responsibilities. If I am participating in leading a children's theatre program, then it is my responsibility to understand essential aspects of the benefits and potential outcomes that a theatre program can have on the lives of the children in my school district.

Moreover, the Bible is clear that children are of great importance to God. In Matthew 19, Jesus made time to be with children and to care for them. He is our example in how we must relate to children in this world. Having learned of the perceived residual effects of participation in a children's program, involvement in such a program as a director and mentor is one way in which I can follow Christ's example. If a stronger social network is created between mentor and student, then that creates a situation in which students can be ministered to in the name of Christ and my life becomes an investment in theirs.

Scripture does not mention theatre, specifically. In Matthew 6:16, Jesus did use the same Greek word for "hypocrite," which was "actor." Some Christians use this verse to conclude that theatre and acting were not approved by God (Morgan, 1966). However, the arts and creativity is displayed throughout the Bible and many instances exist in which dramatic components are utilized in Scripture. For example, the first divine trait revealed in Genesis was that of God as the creator. We are made in the image of God; therefore, we are creative creatures. One of the most striking commentaries on the 
importance of artists and creativity in Scriptures occurs in Exodus 31:1-5. Bazalel, the son of Uri, was the first man God described as being filled with the Spirit: "I have filled him with the Spirit of God, with skill, ability and knowledge in all kinds of crafts - to make artistic designs for work in gold, silver and bronze, to cut and set stones, to work in wood, and to engage in all kinds of craftsmanship." He was an artist chosen by God to use his gifts to glorify Him through obedience to His calling. In another artistic moment of worship, David danced in worship to God as the Ark of the Covenant was carried into the city. Performance itself is used in Ezekiel 4:1-8 when God details a plan for Ezekiel to dramatize the siege of Jerusalem. In this narrative, God is using the tool of theatre to model a picture for the people of Israel.

In a Christian school, teachers and staff members who lead a theatre program can share these truths openly with the students. Additionally, John Eldredge (2004) said: "Every story, great and small, shares the same essential structure because every story we tell borrows its power from a Larger Story, a Story woven into the fabric of our being" (p.12). Christian school teachers also can discuss openly how stories dramatized on stage model truths from Scripture. However, public school teachers are more limited in the open discussion of such truths. Instead, a Christian teacher organizing a theatre program in a public school must focus on shaping the creative gifts God has given the students. Eventually, students who receive Christ through salvation may be able to see more clearly how the gifts God has given them can be used to bring Him glory.

\section{Relation of the Results to Literature}

Much of the findings of this study align congruently with the literature pertaining to creative drama and extracurricular activities. However, there were two main 
exceptions to this alignment. First, Barnett and Weber's (2008) study of mothers' perceptions of extracurricular activities reported that the mothers believed participation in theatre enhanced creativity, but that it had no relation to social skills. Student responses in the present study indicated that social skill enhancement was a prime positive effect of their participation. Not one student discussed experiencing enhanced creativity. Perhaps the difference in the sample group, one evaluating the parents' perceptions and the other evaluating the students' perceptions, accounted for the seemingly contradictory findings. Each group may view the overall effects of participation in elementary programs differently due to their respective vantage points.

Another seemingly contradictory finding concerned the academic component of grades. Some of the published research literature concerning academic effects discussed grades and specific subject areas that were improved as a result of participation in extracurricular activities (Broh, 2002; Darling, 2005; Fredricks \& Eccles, 2006). However in this present study, the student interviews reported specific academic skills learned, such as memorization and public speaking skills, without mention of grades or academic achievement. This may be due to the differences in the format of the study. The literature findings came from longitudinal data which included grades as a component. Whereas, this present study focused on the perceptions of the students involved in the program with no data specifically given or requested concerning grades.

The findings of the present study were consistent with much of the research relating to personal effects for students involved in extracurricular activities. For example, the high school students involved in a study conducted by Larson and Brown (2007) discussed how they were able to address feelings of anxiety through peer support. 
The adolescents' responses in the present study revealed similar findings. Therefore, this study seems to extend the previous literature's findings to elementary school plays.

The research literature discussed school connectedness or bonding, self-esteem, and self-confidence as potential outcomes of high school extracurricular activities in general (Bates, 2007; Cosden et al., 2004; Dotterer et al., 2007). The qualitative findings of the present study revealed essentially the same positive outcomes for elementary school plays as were evidenced in students' high school extracurricular activities. That is, the majority of adolescents involved in the elementary children's theatre study spoke of self-confidence as one perceived outcome that developed through participation in the elementary plays, just as the previous literature demonstrated development of self-esteem as a result of participation in high school extracurricular activities.

Another theme in the present study that was consistent with the previous research literature involved social skills and networks. Students in Yassa's (1999) study reported that they listened to other high school students' varying ideas as they incorporated creative drama in high school classes. They also attempted to accomplish their goals despite differing viewpoints through compromise. Similarly, students in this current study reported learning to use teamwork in order to accomplish their goals of successfully presenting an elementary school play. Therefore, the results of the present study seemingly extend Yassa's (1999) previous findings regarding the use of creative drama in high school to elementary school plays.

Finally, in Pitts' (2007) study regarding the high school musical production of Anything Goes, high school students reported their perceptions and responses concerning the costs and benefits of participation in a high school musical. The high school students 
discussed that the program in which they participated provided social opportunities and friendships. Furthermore, they reported an enhanced relationship between teachers and students as a result of participation in the musical, and they developed a respect for the leader of the musical, as well. Students from this present study similarly reported multiple friendships that developed as a result of participation in an elementary school play. These students also developed a strong relationship with their director. Therefore, the present study provides further evidentiary support for enhanced student relationships, extending the research past high school plays and into the realm of elementary school plays.

Strengths of the Study

This phenomenological study was one of the first of its kind, in that it had a narrow focus of one specific extracurricular activity in an elementary school setting. Relatively little research has been conducted in the field of elementary extracurricular activities, particularly school sponsored activities. As a qualitative study, investigator triangulation strengthened the validity. The use of two, third-party interviewers provided multiple observers to collect and interpret the data. Throughout the interview process, multiple discussions occurred concerning observations of student behaviors and responses. Additionally, interpretive validity was maintained through the use of lowinference descriptors. Wherever possible, I reported students' responses verbatim in order to relay, as much as possible, the participant's interpretations and meanings. Also, I enlisted peer review in order to help ensure the validity of my findings. Throughout the research and writing process, I discussed the findings with my educational peers to allow for additional feedback. This study also incorporated two methods in order to enhance 
internal validity. By using both methods of data collection, interviews and a focus group, I was able to strengthen the study's findings.

Saturation of data occurred, as well. As a phenomenological study, the sample size was generally adequate for the intended purpose. I interviewed all students, providing a rich data set. Upon completion, the first set of interviews were transcribed and coded. After determining the major themes from the data set, another wave of interviews was conducted with approximately half of the sample. Following the second round of interviews, a focus group met in order to discuss the results of the first two interview processes. The second wave of interviews was transcribed, as was the focus group session. Upon organization of the second wave, two realities were relatively clear. First, the results were consistent. Second, saturation of data had been met. Due to the nature of the age and maturity of the participants in the study, additional data collection would be unnecessary and unhelpful to accomplish the study's aim.

\section{Limitations of the Study}

Remaining threats to internal validity. One of the main threats to the study's internal validity is that some perceived effects could have been caused by other factors and experiences, in addition to participation in the school play. For instance, some of the students had participated in theatre programs in middle school and junior high. Often, those experiences would be discussed in the interview process, along with reflection of the elementary experiences. However, I maintain that additional life experiences do not detract from the results, they simply add to them.

Another potential drawback was the use of purposive sampling, as opposed to random sampling. Students who were interviewed met the requirements for participation 
in the study, and no other participants were interviewed. The fact that the students in the sample were the leading actors in the plays may have skewed the results because it is possible that these students already possessed some of the qualities they attributed to learning via their involvement with the school play.

Lack of data triangulation also could have affected the internal validity of the results. Extending the interviews to parent perceptions and teacher perceptions of the effects of the school play would have generated much more data in order to corroborate the findings reported in the present study. However, the organization of such an endeavor was above what I could have reasonably accomplished in this present research study.

A final potential threat to the internal validity of the findings of this study is researcher bias. I was the children's play director throughout all four years of the program. Although I used a third party interviewer, and tried to separate myself from involvement in the interview process, I was still in the building as a representative of the school district in order to ensure the legality of the situation. Due to my proximity, students could have claimed a connection to me, when it is possible that the connection had never existed.

Remaining threats to external validity. The homogenous nature of the sample was a threat to the external validity of the research. Students were all Caucasians, of middle socioeconomic background, live in a rural community, and reside in the Midwestern portion of the United States. Therefore, the results of the student perceptions cannot be generalized to all elementary students throughout the United States. Students of lower or high socioeconomic communities may generate different responses and 
results. In order to generalize the information effectively, the study could be replicated fairly easily within the various socioeconomic communities, which would generate more data and could potentially be beneficial for school districts across the United States. Suggestions for Future Research.

Additional qualitative studies that replicate the present one. First, this particular study could be replicated in schools of median, low, and high socioeconomic communities. That is, future qualitative studies could investigate whether the current findings are consistent for students involved in children's theatre plays from all socioeconomic levels. Second, qualitative research could be conducted regarding student perceptions of other extracurricular activities in elementary, such as sports, art, or photography. Future studies could examine whether the perceived benefits of participation in elementary extracurricular activities extend to the participation of other elementary activities and clubs.

Other qualitative studies should involve analyzing the parent and teacher perceptions of children's participation in school plays. Both parents and teachers possess valuable insights regarding how the play affected the children. By including parental perception, as well as teacher perception, of the effects of participation in an elementary children's play, the findings would form a more plenary understanding of the perceived outcome. As a result of including these perceptions, it may be possible to see the true effects more clearly. Another benefit of conducting qualitative studies involving teachers and parents is that the adults potentially have a larger vocabulary, and they may be able to articulate their thoughts more clearly through enhanced language skills, providing more succinct data. 
While qualitative findings are beneficial, especially in the realm of theatre and dramatic arts, quantitative studies also would provide meaningful data in order to better understand how school plays affect children. One potential future quantitative research project would be to analyze the results of participation in an elementary extracurricular activity as part of a longitudinal study. It is possible that adolescents may not fully grasp the true effects of participation in a play until adulthood. That is, the students' youth can limit their ability to fully recognize the outcomes of participation in the play clearly until they are older. Or, they may not be able to verbalize what they perceive to be true until they are older. By conducting a longitudinal study, data can be assembled over time providing a more clear understanding of the effects of participation in an elementary children's play. 
APPENDIX A

FIRST WAVE INTERVIEW QUESTIONS

\section{$\underline{\text { Residual and Reusable Skills }}$}

- How did you feel about the auditions? Had you ever participated in an audition for a team or group before you auditioned for the play? If yes, how did the auditions for the play compare to them? What, if anything, did you learn about the process of auditioning?

- Have you auditioned or tried out for any other teams or groups since you participated in the play? If yes, do you feel as if auditioning for the play helped to prepare you in any way for them? In what ways, specifically?

- What skills did you develop or use during the practices for the play? What were some of the highlights for you during the practices?

- Do you feel as if you have used these skills in other areas of your life since the play? If so, where and how?

- What do you remember about the experience of performing for your friends and teachers during the school performance? 
- What about performing for your parents? How did you feel that night? What were you thinking as you were on stage?

- Do you feel that performing the play for an audience prepared you in any way for any activities that you have participated in since? Please explain.

- Did your experience with the play encourage or discourage you to continue to participate in other extracurricular activities? Explain your answer.

- Have you participated in any other theatre or drama experiences since you were in the school play? If yes, what were they?

- Do you feel as if participation in the school play benefited your life in any way? If so, how?

\section{Connecting to School/Peers}

- Do you feel participation with the school play in Elementary connected you to the school in any unique way? If yes, explain.

- Did you observe any changes in how you related to the teachers or building leaders after you participated in the play? 
- Did you observe any changes in how you related to your friends and peers in the building after you participated in the play?

- Did you form any specific friendships while working on the play? Did you connect with any other students as a result of performing in the play together?

- Did you feel a sense of teamwork with the other students in the play?

\section{$\underline{\text { Self Esteem }}$}

- What did you learn about yourself after participating in the school play?

- Do you think you improved as a person in any way because you were in the school play?

- How did you feel about having a larger part in the school play?

\section{Closing Up}

- Was there any other effect that the play had on your life that you haven't yet mentioned? 


\section{APPENDIX B}

\section{SECOND WAVE INTERVIEW QUESTIONS}

Round 2: (At the beginning of the interview, tell the students that we especially want to hear about stories and experiences from the play if they will help answer the questions in a specific way.)

1. Do you feel as if you connected to members of the cast in a way that lasted longer than the term of the play? Specifically, which people do you have a continued interaction with? Feel free to share your experiences during the play concerning these individuals as well as how you have interacted since the play.

2. If you have been involved in theatre experiences since the play, do you feel as if participating in the play motivated you to continue to be involved in other plays? If yes, explain what it was about your experiences that caused you to want to be in future plays?

3. Are there any specific memories that you have of your experiences in the play that you feel affected your confidence in yourself? If so, what were they?

4. Do you feel as if participation in the play taught you anything about how to deal with fears? If so, how?

5. What, if anything, did you learn about working with a team? 
6. Did you feel as if you were recognized in any special way after people saw you in the play? For instance, did you receive any flowers or special treatment for participating in the play? If yes, do you feel as if those experiences have impacted your life in any way?

7. What, if anything, did participation in the play teach you how to deal with making mistakes?

8. What, if anything, did participation in the play teach you about being responsible?

9. What, if anything, did participation in the play teach you about working hard?

10. What, if anything, did participation in the play teach you about practice or preparation?

11. Were there any specific examples of how you related to teachers in school because of the play? For example, was there a teacher who encouraged you in a meaningful way, or was there a moment that you felt connected to a teacher differently because of your involvement with the play?

12. Share any other meaningful memories that you have of your experiences in the play? 
APPENDIX C

PARENTAL CONSENT FORM

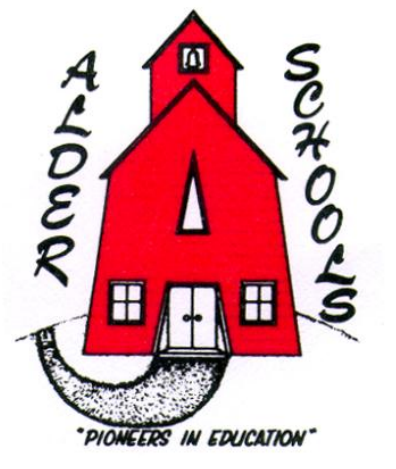

Plain City Elementary School
340 West Main Street
Plain City, Ohio 43064

Doug Carpenter

Kelly Hicks, Principal

Superintendent

Phone: (614) 873-4608

(614) 873-5621

Fax: (614) 873-2559

To the Parents of

Hello. My name is Karen (Campbell) Dietry. I am a teacher at Plain City Elementary, but you may remember me as the director of your child's elementary play. I am in the final stages of completing my Masters in Education through Cedarville University, and my thesis is on the residual effects of participation in a youth theatre program. As part of the research, I plan to interview students involved in the PCE theatre program to ascertain student perceptions of the effects of involvement with the plays.

I would like to interview your child as part of this study. Because your child is a minor, I need both their agreement to participate and your permission before I can complete the interview process. To maintain research authenticity, I will be having a third party complete the interviews on my behalf. However, I will be supervising the interviews and all interviews will be taped and transcribed. I will be happy to provide your family a copy of your child's interview, if you so choose. The research will be kept confidential, and names will be changed in any reports.

Most of the interviews will be conducted after school or on a Saturday. Some interviews will be completed during your student's study hall. It is my goal to work around your child's schedule, as much as possible. All interviews will take place at your child's school or at Plain City Elementary during the months of March and, if necessary, April. There is also the possibility of a focus group being formed to garner students' collective ideas regarding the theatre program. Each participating student will receive a small gift as a token of my appreciation for their participation.

Thank you so much for your consideration of and potential help in the completion of my Master's requirements for graduation. Please sign and return the permission slip below in the enclosed envelope by February 13, 2009. If you have any further questions about the research study, feel free to call me at 614850-9779. I will be happy to discuss the project in further detail.

Sincerely,

Karen Dietry 


\section{Residual Effects Research Study Permission Slip}

I give permission for my student to participate in an interview regarding his/her perceptions of involvement with the Plain City Elementary Theatre Program. I also grant permission for the interview to be taped and transcribed. I understand that confidentiality will be maintained.

Student's Name (please print):

Student's Signature:

Parent's Signature:

Date: 


\section{REFERENCES}

Akos, P. (2006). Extracurricular participation and the transition to middle school. Research in Middle Level Education Online, 29, 1-9.

Barnett, L. (2007). "Winners" and "losers:" The effects of being allowed or denied entry into competitive extracurricular activities. Journal of Leisure Research, 39, 316-344.

Barnett, L., \& Weber, J. (2008). Perceived benefits to children from participating in different types of recreational activities. Journal of Park and Recreation Administration, 26, 1-20.

Bates, L. (2007). The play's the thing, literary adaptations for children's theatre. International Journal of Early Childhood, 39, 37-44.

Beales, J., \& Zemel, B. (1990). The effects of high school drama on social maturity. School Counselor, 38, 46-51.

Bereska, T. M. (2003). How will I know a code when I see it? Qualitative Research Journal, 3, 60-74.

Bergen, D. (2008). Human development. Upper Saddle River, NJ: Prentice Hall.

Blomfield, C., \& Barber, B. (2010). Australian adolescent's extracurricular activity participation and positive development: Is the relationship mediated by peer attributes? Australian Journal of Educational and Developmental Psychology, 10, 114-128. 
Boldt, R., \& Brooks, C. (2006). Creative arts: Strengthening academics and building community with students at-risk. Reclaiming Children and Youth, 14, 223-227.

Broh, B. (2002). Linking extracurricular programming to academic achievement: Who benefits and why? Sociology of Education, 75, 69-91.

Brown, S. L., Nobiling, B. D., Teufel, J., Birch, \& D. A. (2011). Are kids too busy? Early adolescents' perceptions of discretionary activities, overscheduling, and stress. Journal of School Health, 81, 574-580.

Button, S., \& Millward, P. (2006). Preparing for drama. Education 3-13, 34, 73-79.

Casale, M., \& Hanass-Hancock, J. (2011). Of drama, dreams and desire: Creative approaches to applied sex education in southern Africa. Sex Education, 11, 353368.

Cassel, R., Chow, P., Demoulin, D., \& Reiger, R. (2001). Extracurricular involvement in high school produces honesty and fair play needed to prevent delinquency and crime. Education, 121, 247-251.

Chambers, E., \& Schreiber, J. (2004). Girls academic achievement: Varying associations of extracurricular activities. Gender and Education, 16, 327-346.

Cockett, S. (1999). Evaluating children's learning in drama in the primary school. Westminster Studies in Education, 22, 63-73.

Cope, C. (2004). Ensuring validity and reliability in phenomenographic research using the analytical framework of a structure of awareness. Qualitative Research Journal, 4, 5-18. 
Cosden, M., Morrison, G., Gutierrez, L., \& Brown, M. (2004). The effects of homework programs and after-school activities on school success. Theory into Practice, 43, 220-226.

Cousins, H. (2000). Upholding mainstream culture: The tradition of the American high school play. Research in Drama Education, 5, 85-94.

Creswell, J. (2013). Qualitative inquiry and research design: Choosing among five approaches. Thousand Oaks, CA: SAGE.

Dalrymple, L. (2006). Has it made a difference? Understanding and measuring the impact of applied theatre with young people in the South African context. Research in Drama Education, 11, 201-218.

Darling, N. (2005). Participation in extracurricular activities and adolescent adjustment: cross-sectional and longitudinal findings. Journal of Youth and Adolescence, 34, 493-505.

Del Rio-Roberts, M. (2011). How I learned to conduct focus groups. Qualitative Report, $16,312-315$.

Deese, J. (1957). Serial organization in the recall of disconnected items. Psychological Reports, 3, 577-582.

Dotson, K., \& Grimes, C. (2010). The graduation project: Research in action. Teacher Librarian, 37, 59-64.

Dotterer, A., McHale, S., \& Crouter, A. (2007). Implications of out-of-school activities for school engagement in African American adolescents. Journal of Youth Adolescence, 36, 391-401. 
Dufresne, J. (2006). Crime is easy, Shakespeare is hard. Reclaiming Children and Youth, $14,245-248$.

Dumais, S. (2006). Elementary school students' extracurricular activities: The effects of participation on achievement and teachers' evaluations. Sociological Spectrum, $26,117-147$.

Dwyer, J., \& Neuman, S. B. (2008). Selecting books for children birth through four: A developmental approach. Early Childhood Education Journal, 35, 489-494.

Eccles, J., Barber, B., Stone, M., \& Hunt, J. (2003). Extracurricular activities and adolescent development. Journal of Social Issues, 59, 865-889.

Eldredge, J. (2004). Epic: The story God is telling and the role that is yours to play. Nashville, TN: Thomas Nelson.

Faircloth, B., \& Hamm, J. (2005). Sense of belonging among high school students representing 4 ethnic groups. Journal of Youth and Adolescence, 34, 293-309.

Farris, P., \& Parke, J. (1993, March/April). To be or not to be: What students think about drama. Clearing House, 66(4), 231-234.

Feldman, R. (2001). Social psychology ( ${ }^{\text {rd }}$ Ed.). Upper Saddle River, NJ: Prentice-Hall. Feldman, R. (2009). Discovering the life span. Upper Saddle River, NJ: Prentice-Hall. Fereday, J., \& Muir-Cochrane, E. (2006). Demonstrating rigor using thematic analysis: A hybrid approach of inductive and deductive coding and theme development. International Journal of Qualitative Methods, 5(1), 80-92. Retrieved November 12, 2009, from http://www.ualberta.ca/ iiqm/backissues/5_1/pdf/fereday.pdf. 
Firmin, M. (2006). Using interview waves in qualitative phenomenological research. In P. Brewer \& M. Firmin (Eds.), Ethnographic and Qualitative Research, Vol. 1. (pp.175-181). New Castle, UK: Cambridge Scholars Press.

Fleming, M., Merrell, C., \& Tymms, P. (2004). The impact of drama on pupils' language, mathematics, and attitude in two primary schools. Research in Drama Education, 9, 177-197.

Fredricks, J., \& Eccles, J. (2005). Developmental benefits of extracurricular involvement: Do peer characteristics mediate the link between activities and youth outcomes? Journal of Youth and Adolescence, 34, 507-520.

Fredricks, J., \& Eccles, J. (2006). Extracurricular involvement and adolescent adjustment: Impact of duration, number of activities, and breadth of participation. Applied Developmental Science, 10, 132-146.

Fredricks, J. (2012). Extracurricular participation and academic outcomes: Testing the over-scheduling hypothesis. Journal of Youth and Adolescence, 41, 295-306.

Freeman, G., Sullivan, K., \& Fulton, C. (2003). Effects of creative drama on self-concept, social skills, and problem behavior. The Journal of Educational Research, 96, $131-137$.

Furman, L. (2000). In support of drama in early childhood education, again. Early Childhood Education Journal, 27, 173-177.

Gabrielle, R. (2008). Orientations to happiness: Do they make a difference in a student's educational life? American Secondary Education, 36, 88-101. 
Gadbois, S., \& Bowker, A. (2007). Gender differences in the relationships between extracurricular activities participation, self-description, and domain-specific and general self-esteem. Sex Roles, 56, 675-689.

Gilman, R., Meyers, J., \& Perez, L. (2004). Structured extracurricular activities among adolescents: Findings and implications for school psychologists. Psychology in the Schools, 41, 31-41.

Guest, A., \& Schneider, B. (2003). Adolescents' extracurricular participation in context: The mediating effects of schools, communities, and identity. Sociology of Education, 76, 89-109.

Hansen, D., Larson, R., \& Dworkin, J. (2003). What adolescents learn in organized youth activities: A survey of self-reported developmental experiences. Journal of Research on Adolescence, 13, 25-55.

Hendricks, C. (2009). Improving schools through action research: A comprehensive guide for educators. Upper Saddle River, NJ: Pearson.

House, J. (2000). The effect of student involvement on the development of academic selfconcept. The Journal of Social Psychology, 140, 261-263.

Howie, L., Lukacs, S., \& Pastor, P. (2010). Participation in activities outside of school hours in relation to problem behavior and social skills in the middle childhood. Journal of School Health, 8, 119-125.

Hughes, J., \& Wilson, K. (2004). Playing a part: The impact of youth theatre on young people's personal and social development. Research in Drama Education, 9, $57-72$. 
Hunt, H. (2005). The effect of extracurricular activities in the educational process: Influence on academic outcomes? Sociological Spectrum, 25, 417-445.

Jindal-Snape, D., Vettraino, E., Lowson, A., \& McDuff, W. (2011). Using creative drama to facilitate primary-secondary transition. Education 3-13, 39, 383-394.

Johnson, A. P. (2008). A short guide to action research ( $3^{\text {rd }}$ ed.). Boston: Pearson.

Johnson, B., \& Christensen, L. (2004). Educational research: Quantitative, qualitative, and mixed approaches. Boston: Pearson.

Johnson, R. B. (1997). Examining the validity structure of qualitative research. Education, 118, 282-292.

Johnson, C. (2002). Drama and metacognition. Early Child Development and Care, 172, 595-602.

Joronen, K., Konu, A., Rankin, H. S., \& Astedt-Kurki, P. (2012). An evaluation of a drama program to enhance social relationships and anti-bullying at elementary school: A controlled study. Health Promotion International, 27, 5-14.

Kelin, D. (2007). Minding the moment. Teaching Artist Journal, 5, 104-112.

Kisiel, C., Blaustein, M., Spinazzola, J., Schmidt, C., Zucker, M., \& van der Kolk, B. (2006). Evaluation of a theater-based youth violence prevention program for elementary school children. Journal of School Violence, 5, 19-36.

Klem, A., \& Connell, J. (2004). Relationships matter: Linking teacher support to student engagement and achievement. Journal of School Health, 74, 262-273.

Knifsend, C., \& Graham, S. (2012). Too much of a good thing? How breadth of extracurricular participation relates to school-related affect and academic outcomes during adolescence. Journal of Youth and Adolescence, 41, 379-389. 
Kvale, S. (2007). Doing Interviews. Thousand Oaks, CA: SAGE.

Lagace-Seguin, D., \& Case, E. (2010). Extracurricular activity and parental involvement predict positive outcomes in elementary school children. Early Child Development and Care, 180, 453-462.

Larson, R., \& Brown, J. (2007). Emotional development in adolescence: What can be learned from a high school theater program? Child Development, 78, 10831099.

Leedy, P. D., \& Ormrod, J. E. (2010). Practical research $\left(9^{\text {th }}\right.$ Ed.). Boston: Pearson. Liamputtong, P. (2011). Focus group methodology: Principles and practice. Thousand Oaks, CA: SAGE.

Lichtman, M. (2013). Qualitative research in education: A user's guide ( ${ }^{\text {rd }}$ Ed.). Thousand Oaks, CA: SAGE.

Lipscomb, S. (2007). Secondary school extracurricular involvement and academic achievement: A fixed effects approach. Economics of Education Review, 26, 463-472.

Maples, J. (2007, July/August). English class at the improv: Using improvisation to teach middle school students confidence, community and content. The Clearing House, $80(6), 273-277$.

Maxwell, J. A. (2005). Qualitative research design: An interactive approach $\left(2^{\text {nd }} \mathrm{Ed}\right.$.). Thousand Oaks, CA: SAGE.

McMillan, J. (2012). Educational research. Boston: Pearson.

McNeal, Jr., R. (1999). Participation in high school extracurricular activities: Investigating school effects. Social Science Quarterly, 80, 291-309. 
McNeely, C., Nonnemaker, J., \& Blum, R. (2002). Promoting school connectedness: Evidence from the national longitudinal study of adolescent health. Journal of School Health, 72, 138-146.

Mero-Jaffe, I. (2011). 'Is that what I said?' Interview transcript approval by participants: An aspect of ethics in qualtitative research. International Journal of Qualitative Methods, 10, 231-247.

Mertler, C., \& Charles, C. M. (2008). Introduction to educational research $\left(6^{\text {th }}\right.$ Ed.). Boston: Pearson.

Miller, P. (2008). Validity. In L. Given (Ed.), The SAGE encyclopedia of qualitative methods (pp. 909-910). Thousand Oaks, CA: SAGE.

Molinuevo, B., Bonillo, A., \& Pardo, Y. (2010). Participation in extracurricular activities and emotional and behavioral adjustment in middle childhood in Spanish boys and girls. Journal of Community Psychology, 38, 842-857.

Morgan, E. S. (1966). Puritan hostility to the theatre. Proceedings of the American Philosophical Society, 110, 340-347.

Munier, A., \& Etherton, M. (2006). Child rights theatre for development in rural Bangladesh: A case study. Research in Drama Education, 11, 175-183.

Ohio Department of Education. (2012). Revised Academic Content Standards and Model Curriculum Development. Retrieved from http://education.ohio.gov.

Olszewski-Kubilius, P., \& Lee, S. (2004). The role of participation in in-school and outside-of-school activities in the talent development of gifted students. The Journal of Secondary Gifted Education, 15, 107-123. 
Patton, M. Q. (2001). Qualitative evaluation and research methods. ( $3^{\text {rd }}$ Ed.). Thousand Oaks, CA: SAGE.

Peck, S., Roeser, R., Zarrett, N., \& Ecces, J. (2008). Exploring the roles of extracurricular activity quantity and quality in the educational resilience pattern-centered approaches. Journal of Social Issues, 64, 135-155.

Pitts, S. (2007). Anything goes: A case study of extra-curricular musical participation in an English secondary school. Music Education Research, 9, 145-165.

Raffanti, M. (2007). Grounded theory in educational research: Exploring the concept of 'groundedness.' In M. Firmin \& P. Brewer (Eds.), Ethnographic \& qualitative research in education, Vol. 2. (pp. 61-74). NewCastle, UK: Cambridge Scholars Press.

Rodgers, B. L. (2008). Audit trail. In L. Given (Ed.), The SAGE encyclopedia of Qualitative Research Methods Volume 1 (pp. 433-444). Thousand Oaks, CA: SAGE.

Rosler, B. (2008, November/December). Process drama in one fifth-grade social studies class. The Social Studies, 99 (6) 265-272.

Rubin, H., \& Rubin, I. (1995). Qualitative interviewing: The art of hearing data. Thousand Oaks, CA: SAGE.

Salkind, N. (2009). Exploring research ( $7^{\text {th }}$ Ed.) Upper Saddle River, NJ: Prentice-Hall. Shirer, N. (2005). My true voice: Fundamental content, individual capability, social progress. Arts Education Policy Review, 106, 25-33. 
Shulruf, B. (2010). Do extra-curricular activities in schools improve educational outcomes? A critical review and meta analysis of the literature. International Review of Education, 56, 591-612.

Silverman, D. (2006). Interpreting qualitative data $\left(3^{\text {rd }}\right.$ Ed.). Thousand Oaks, CA: SAGE.

Sin, S. (2010). Considerations of quality in phenomenological research. International Journal of Qualitative Methods, 9, 305-319.

Spaulding, D.T., \& Falco, J. (2012). Action research for school leaders. Boston: Pearson.

Walsh-Bowers, R., \& Basso, R. (1999). Improving early adolescents’ peer relations through classroom creative drama: An integrated approach. Social Work in Education, 21, 23-32.

Wertz, F., Charmaz, K., McMullen, L., Josselson, R., Anderson, R., \& McSpadden, E. (2011). Five ways of doing qualitative analysis: Phenomenological psychology, grounded theory, discourse analysis, narrative research, and intuitive inquiry. New York: The Guildford Press.

Wilkinson, S. (1997), Focus group research. In D. Silverman (Ed.), Quantitative research: Theory, method and practice. (pp. 177-199). Thousand Oaks, CA: SAGE.

Wright, P. (1999). The thought of doing drama scares me to death. Research in Drama Education, 4, 227-237.

Yassa, N. (1999). High school involvement in creative drama. Research in Drama Education, 4, 37-49. 